\title{
Article \\ Vanadium(V) Complexes with Siderophore Vitamin E-Hydroxylamino-Triazine Ligands
}

\author{
Maria Loizou ${ }^{1}$, Ioanna Hadjiadamou ${ }^{1}\left(\mathbb{D}\right.$, Chryssoula Drouza $\left.{ }^{2, *} \mathbb{(}\right)$, Anastasios D. Keramidas ${ }^{1, *} \mathbb{D}$, \\ Yannis V. Simos ${ }^{3, *}$ and Dimitrios Peschos ${ }^{3}$ \\ 1 Department of Chemistry, University of Cyprus, Nicosia 2901, Cyprus; loizou.maria@ucy.ac.cy (M.L.); \\ hadjiadamou.ioanna@ucy.ac.cy (I.H.) \\ 2 Department of Agricultural Production, Biotechnology and Food Science, Cyprus University of Technology, \\ Limassol 3036, Cyprus \\ 3 Department of Physiology, Faculty of Medicine, School of Health Sciences, University of Ioannina, \\ 45110 Ioannina, Greece; dpeschos@uoi.gr \\ * Correspondence: chryssoula.drouza@cut.ac.cy (C.D.); akeramid@ucy.ac.cy (A.D.K.); isimos@uoi.gr (Y.V.S.); \\ Tel.: +357-2289-2764 (A.D.K.); Fax: +357-2289-5454 (A.D.K.)
}

check for updates

Citation: Loizou, M.; Hadjiadamou, I.; Drouza, C.; Keramidas, A.D.; Simos, Y.V.; Peschos, D. Vanadium(V) Complexes with Siderophore Vitamin E-Hydroxylamino-Triazine Ligands. Inorganics 2021, 9, 73. https:// doi.org/10.3390/inorganics 9100073

Academic Editor: Dinorah Gambino

Received: 21 July 2021

Accepted: 27 September 2021

Published: 29 September 2021

Publisher's Note: MDPI stays neutral with regard to jurisdictional claims in published maps and institutional affiliations.

Copyright: (c) 2021 by the authors. Licensee MDPI, Basel, Switzerland. This article is an open access article distributed under the terms and conditions of the Creative Commons Attribution (CC BY) license (https:/ / creativecommons.org/licenses/by/ $4.0 /)$.

\begin{abstract}
Novel vitamin E chelate siderophore derivatives and their $\mathrm{V}^{\mathrm{V}}$ and $\mathrm{Fe} \mathrm{III}^{\mathrm{II}}$ complexes have been synthesised and the chemical and biological properties have been evaluated. In particular, the $\alpha$ - and $\delta$-tocopherol derivatives with bis-methyldroxylamino triazine ( $\alpha$-tocTHMA) and ( $\delta$-tocDPA) as well their $\mathrm{V}^{\mathrm{V}}$ complexes, $\left[\mathrm{V}_{2}{ }^{\mathrm{V}} \mathrm{O}_{3}(\alpha \text {-tocTHMA })_{2}\right]$ and $\left[\mathrm{V}_{2}{ }^{\mathrm{IV}} \mathrm{O}_{3}(\delta \text {-tocTHMA })_{2}\right]$, have been synthesised and characterised by infrared (IR), nuclear magnetic resonance (NMR), electron paramagnetic resonance (EPR) and ultra violet-visible (UV-Vis) spectroscopies. The dimeric vanadium complexes in solution are in equilibrium with their respefrctive monomers, $\mathrm{H}_{2} \mathrm{O}+\left[\mathrm{V}_{2}{ }^{\mathrm{V}} \mathrm{O}_{2}(\mu-\mathrm{O})\right]^{4+}=2\left[\mathrm{~V}^{\mathrm{V}} \mathrm{O}(\mathrm{OH})\right]^{2+}$. The two amphiphilic vanadium complexes exhibit enhanced hydrolytic stability. EPR shows that the complexes in lipophilic matrix are mild radical initiators. Evaluation of their biological activity shows that the compounds do not exhibit any significant cytotoxicity to cells.
\end{abstract}

Keywords: vanadium; vitamin E; EPR; tocopherol; ${ }^{51}$ V NMR

\section{Introduction}

The understanding of the physiological role of vanadium ions in biological systems as well as the biological activity of vanadium compounds have stimulated the interest of the scientific community towards the vanadium chemistry [1-8]. Pharmaceuticals based on vanadium complexes have attracted the interest of scientists due to the biological activity of vanadium molecules and their low toxicity [4,5,9-19]. In addition, vanadium compounds exert antitumor effects through activation of apoptotic pathways, cell cycle arrest and the generation of Reactive Oxygen Species (ROS), inducing lower toxicity than anticancer platinum-based molecules [4,20-25].

$\alpha$-Tocopherol acts in biological organisms as a strong lipophilic antioxidant, without any other biological activity. However, the vitamin E (tocopheryl and tocotrienyl) derivatives, such as $\alpha$-tocopheryl succinate, have anticancer properties [26-34]. The hydrophobic domain of the vitamers of vitamin $\mathrm{E}$ is responsible for docking the agents in circulating lipoproteins and biological membranes [35]. Conjugate molecules of vitamin E vitamers with pharmaceuticals, such as metal complexes, can be used to transfer the drug in the active site of vitamin $\mathrm{E}$ vitamers, inducing biological responses.

Recently, we reported the first study of the synthesis of complexes comprising tocopherol ligating to metals [36]. The ligands in this study are $\beta$-tocopherol molecules substituted with chelate groups in $o$-position derivatives (Scheme $1, \mathrm{H}_{3} \beta$-tocDEA), thus, enabling coordination of the metal ion from the phenolic oxygen. The [ $\mathrm{V}^{\mathrm{V}} \mathrm{O}(\beta$-tocDEA $\left.)\right]$ has been found to be cytotoxic to cancer cells. Some of the features of these amphiphilic 
<smiles>[R]Oc1nc(N(C)O)nc(N(C)O)n1</smiles>

$\mathrm{H}_{2}$-toc THMA

or

$\mathrm{H}_{2}$-tocTHMA vanadium complexes have been their ability to induce the formation of free radicals [37], and their higher stability in aqueous solutions than the respective counterparts deprived of their lipophilic part. The hydrolytic stability of the vanadium complexes is enhanced in amphiphilic media $[36,38,39]$, therefore, the high hydrolytic stability of the amphiphilic vanadium complexes has been attributed to their amphiphilic nature; presumably through a more favourable solvation [40].

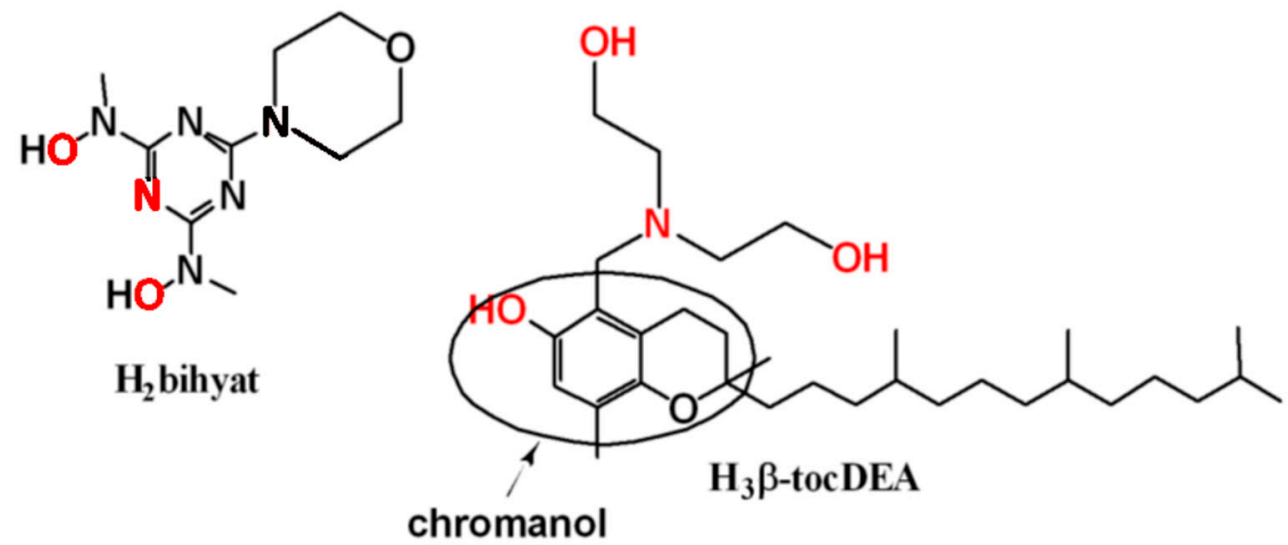

Scheme 1. Hydroxylamino-triazine ligands and $\mathrm{H}_{3} \beta$-tocDEA. $\mathrm{RO}$ - is $\alpha$-or $\delta$-tocopherol. The donor atoms for metal ion coordination are in red colour.

Herein, we have attached a siderophore moiety on the phenoxy oxygen of the chromanol (Scheme 1), forming two new ligands, the 2,4-dichloro-6-(((R)-2,5,7,8-tetramethyl-2$\left((4 \mathrm{R}, 8 \mathrm{R})-4,8,12\right.$-trimethyltridecyl)chroman-6-yl)oxy)-1,3,5-triazine ( $\mathrm{H}_{2} \alpha$-tocTHMA) and 2,4dichloro-6-(((R)-2,8-dimethyl-2-((4R,8R)-4,8,12-trimethyltridecyl)chroman-6-yl)oxy)-1,3,5triazine $\left(\mathrm{H}_{2} \delta\right.$-tocTHMA). The labile hydrogen atom of the hydroxy group has been replaced with the triazine moiety forming an inert ether bond and, thus, the new organic molecules will act as ligand owing lower antioxidant activity than free tocopherols; the formation of the tocopheryl radical requires deprotonation of chromanol group. In addition, the high lipophilicity of both the tocopherol derivatives and their complexes assures easy penetration in cell membranes [38]. As chelate group for $\mathrm{V}^{\mathrm{V}}$ we have chosen the siderophore hydroxylamino-triazine (Scheme 1), targeting to enhance the hydrolytic stability of the $\mathrm{V}^{\mathrm{V}}$ complexes as much as possible. This chelate group, for example in the ligand $\mathrm{H}_{2}$ bihyat (Scheme 1) forms very strong complexes with hard acids such as $\mathrm{Fe}^{\mathrm{III}}, \mathrm{V}^{\mathrm{V}}, \mathrm{Mo}^{\mathrm{VI}}$ and $\mathrm{U}^{\mathrm{VI}}$ [41-44], with $\mathrm{Fe}^{\mathrm{III}}$ and $\mathrm{U}^{\mathrm{VI}}$ to exert the higher affinity for this chelate coordination. The $\mathrm{V}^{\mathrm{V}}$ complexes of this study exhibiting a chromanol hydroxy group unavailable for coordination, present no significant toxicity to cells. These results are in contrast to the high toxicity of the previous reported vanadium complexes, in which the vanadium ion was coordinated directly with the hydroxy group of the chromanol [36].

\section{Experimental Section}

2.1. Reagents

All reagents were purchased from Aldrich and Merck, (Kenilworth, NJ, USA). Vanadium complexes used for cell viability studies were dissolved in dimethyl sulfoxide (DMSO). DMSO was also used as vehicle control. Microanalyses for $\mathrm{C}, \mathrm{H}$ and $\mathrm{N}$ were performed using a Euro-Vector EA3000 CHN elemental analyser (Milan, Italy). Infrared (IR) spectra were recorder on a Shimadzu Prestige 21, 7102 Riverwood Drive, Columbia, Maryland 21046, U.S.A. MALDI-TOF mass spectra were recorded on a Bruker Autoflex III Smartbeam (Billerica, MA, USA) instrument using $\alpha$-Cyano-4-hydroxycinnamic acid (HCCA) as matrix.

2,2'-((2-hydroxyoctadecyl)azanediyl)bis(ethan-1-ol) (C18DEA), [ $\left.\mathrm{V}^{\mathrm{V}} \mathrm{O}(\mathrm{C} 18 \mathrm{DEA})\right]$ were prepared according to reference [37]. 


\subsection{Synthesis}

2,4-dichloro-6-(((R)-2,5,7,8-tetramethyl-2-((4R,8R)-4,8,12-trimethyltridecyl)chroman-6-yl)oxy)-1,3,5triazine $\left(\mathrm{H}_{2} \alpha\right.$-tocTCL). Cyanuric chloride $(1.86 \mathrm{~g}, 10.0 \mathrm{mmol})$ and $\mathrm{N}, \mathrm{N}$-diisopropylethylamine $(1.45 \mathrm{~g}, 11.2 \mathrm{mmol})$ were dissolved in $40 \mathrm{~mL}$ of THF. The resulting colourless solution cooled at $0{ }^{\circ} \mathrm{C}$. A THF solution $(5 \mathrm{~mL})$ of $\alpha$-tocopherol $(4.31 \mathrm{~g}, 10.0 \mathrm{mmol})$ was added to the above solution. The yellow solution was stirred for $24 \mathrm{~h}$ at room temperature. Then, the solution was evaporated, and the residue was extracted with chloroform/water. The organic phase was evaporated to give a yellow-orange oil as the product $(3.50 \mathrm{~g}, 61 \%) .{ }^{1} \mathrm{H}-\mathrm{NMR},(300 \mathrm{MHz}$, $\left.\mathrm{CDCl}_{3}\right) \delta$ ppm: $0.85-0.88\left(\mathrm{~m}, 12 \mathrm{H},-\mathrm{CH}_{3}\right.$ methyl groups of the tocopherol), $1.12-1.15(\mathrm{~m}$, $6 \mathrm{H}), 1.26$ (br s, 10H), 1.35-1.46 (m, 5H), 1.50-1.58 (m, 3H), 1.80-1.85 (m, C16-H), 1.95-1.99 (d, C8-H, C14-H), 2.12 (s, C10-H), 2.60-2.64 (t, C15-H). Elemental Analysis for $\mathrm{C}_{32} \mathrm{H}_{49} \mathrm{C}_{12} \mathrm{~N}_{3} \mathrm{O}_{2}$ : Found: C, 66.20; H, 8.88; N, 7.13, Calcd.: C, 66.42; H, 8.54; N, 7.26.

2,4-dichloro-6-(((R)-2,8-dimethyl-2-((4R,8R)-4,8,12-trimethyltridecyl)chroman-6-yl)oxy)-1,3,5-triazine $\left(\boldsymbol{H}_{2} \boldsymbol{\delta}\right.$-tocTCL $)$. Cyanuric chloride $(1.95 \mathrm{~g}, 10.6 \mathrm{mmol})$ was dissolved in $40 \mathrm{~mL}$ of THF with the dropwise addition of $\mathrm{N}, \mathrm{N}$-diisopropylethylamine $(1.50 \mathrm{~g}, 11.6 \mathrm{mmol})$ and the solution cooled at $0{ }^{\circ} \mathrm{C}$. To the resulting solution, equivalent quantity of $\delta$-tocopherol $(4.26 \mathrm{~g}$, $10.6 \mathrm{mmol}$ ) dissolved in $5 \mathrm{~mL}$ of THF was added. The solution was left to stir for $24 \mathrm{~h}$ at room temperature and the colour of the solution changed to yellow. The next day the solution was evaporated and extracted with chloroform/water. The chloroform extract was evaporated to give a yellow-orange oil as the product $(3.00 \mathrm{~g}, 52 \%) .{ }^{1} \mathrm{H}-\mathrm{NMR},(300 \mathrm{MHz}$, $\left.\mathrm{CDCl}_{3}\right) \delta$ ppm: $0.87-0.90\left(\mathrm{~m}, 12 \mathrm{H},-\mathrm{CH}_{3}\right.$ methyl groups of the tocopherol), 1.10-1.16 (m, $6 \mathrm{H}), 1.31$ (br s, 10H), 1.36-1.45 (m, 5H), 1.52-1.61 (m, 3H), 1.80-1.87 (m, C16-H), $2.16(\mathrm{~s}$, C10-H), 2.72-2.83 (t, C15-H). Elemental analysis for $\mathrm{C}_{30} \mathrm{H}_{45} \mathrm{C}_{12} \mathrm{~N}_{3} \mathrm{O}_{2}$ : Found: $\mathrm{C}, 65.31 ; \mathrm{H}$, 8.33; N, 7.28, Calcd.: C, 65.44; H, 8.24; N, 7.63.

Synthesis of $N, N^{\prime}-(6-(((R)-2,5,7,8$-tetramethyl-2-((4R,8R)-4,8,12-trimethyltridecyl)chroman-6yl)oxy)-1,3,5-triazine-2,4-diyl)bis( $N$-methylhydroxylamine) ( $\mathrm{H}_{2} \alpha$-tocTHMA). 1st method: $\alpha$ tocTCL $(3.00 \mathrm{~g}, 5.18 \mathrm{mmol})$ was dissolved in THF $(120 \mathrm{~mL})$ at $0{ }^{\circ} \mathrm{C}$. A cooled $\left(0^{\circ} \mathrm{C}\right)$ solution of $\mathrm{N}$-Methylhydroxylamine hydrochloride $(1.80 \mathrm{~g}, 21.5 \mathrm{mmol})$ and sodium hydroxide $(0.86 \mathrm{~g}, 2.2 \mathrm{mmol})$ in water $(10 \mathrm{~mL})$ was added dropwise in the above solution. The reaction mixture was refluxed for $24 \mathrm{~h}$. Then, the solution was evaporated under vacuum to dry, and the residue was extracted with chloroform/water. The organic phase was evaporated under vacuum to dry resulting in $\mathrm{H}_{2} \alpha$-tocTHMA as an orange-brown oil. The yield was $2.1 \mathrm{~g}, 68 \%$.

2nd method: $\alpha$-tocTCL $(3.00 \mathrm{~g}, 5.18 \mathrm{mmol})$ was dissolved in THF $(120 \mathrm{~mL})$ at $0{ }^{\circ} \mathrm{C}$. A cooled $\left(0^{\circ} \mathrm{C}\right)$ solution of $\mathrm{N}$-Methylhydroxylamine hydrochloride $(1.80 \mathrm{~g}, 21.5 \mathrm{mmol})$ and sodium hydroxide $(0.86 \mathrm{~g}, 2.2 \mathrm{mmol})$ in water $(10 \mathrm{~mL})$ was added dropwise to the above solution. The reaction mixture was kept under stirring at room temperature for 4 days. Then, it was evaporated under vacuum to dry, and the residue was dissolved in chloroform and filtrated to remove the insoluble in chloroform $\mathrm{NaCl}$. The solution was evaporated under vacuum to dry yielding $\mathrm{H}_{2} \alpha$-tocTHMA, $2.0 \mathrm{~g}$, $66 \%$ as an orange-brown oil. ${ }^{1} \mathrm{H}-\mathrm{NMR}$, $\left(300 \mathrm{MHz}, \mathrm{CDCl}_{3}\right) \delta \mathrm{ppm}: 0.85-0.90(\mathrm{~m}, 12 \mathrm{H}$ methyl groups of tocopherol), 1.14-1.17 (m, $6 \mathrm{H}), 1.25-1.27$ (br s, 10H), 1.35-1.46 (m, 5H), 1.50-1.57 (m, 3H), 1.79-1.84 (m, C16-H), 1.96-2.00 (d, C8-H, C14-H), 2.11-2.13 (s, C10-H), 2.59-2.62 (t, C15-H), 3.3-2.5 (s, 6H methyl groups of $\mathrm{N}$-methylhydroxylamine). Elemental Analysis for $\mathrm{C}_{34} \mathrm{H}_{57} \mathrm{~N}_{5} \mathrm{O}_{4}$ : Found: $\mathrm{C}$, 68.29; H, 9.31; N, 11.59, Calcd.: C, 68.08; H, 9.58; N, 11.68. [MALDI-TOF(+)-MS]: calcd for $\left(\mathrm{C}_{34} \mathrm{H}_{57} \mathrm{~N}_{5} \mathrm{O}_{4} \mathrm{Na}\right)\left\{[\mathrm{M}+\mathrm{Na}]^{+}\right\} \mathrm{m} / z$ 622.43, found $623.13(100 \%)$.

Synthesis of $N, N^{\prime}-(6-(((R)-2,8-$ dimethyl-2-((4R,8R)-4,8,12-trimethyltridecyl)chroman-6-yl)oxy)1,3,5-triazine-2,4-diyl)bis( $\mathrm{N}$-methylhydroxylamine) $\left(\mathrm{H}_{2} \boldsymbol{\alpha}\right.$-tocTHMA). $\mathrm{H}_{2} \delta$-tocTHMA was synthesised following the same methodology as for the synthesis of $\mathrm{H}_{2} \alpha$-tocTHMA. The yields were $82 \%$ and $53 \%$ for the 1 st and the 2 nd synthetic methods respectively. ${ }^{1} \mathrm{H}-\mathrm{NMR}$, $\left(300 \mathrm{MHz}, \mathrm{CDCl}_{3}\right) \delta \mathrm{ppm}: 0.87-0.90(\mathrm{~m}, 12 \mathrm{H}$ methyl groups of tocopherol), $1.08-1.19(\mathrm{~m}$, $6 \mathrm{H}), 1.26-1.29$ (br s, 10H), 1.36-1.48 (m, 5H), 1.52-1.57 (m, 3H), 1.79-1.81 (t, C16-H), 2.14- 
$2.17(\mathrm{~d}, \mathrm{C} 10-\mathrm{H}), 2.70-2.75(\mathrm{t}, \mathrm{C} 15-\mathrm{H}), 3.3-2.5$ (s, 6H methyl groups of $\mathrm{N}$-methylhydroxylamine), 6.40-6.75 (2 dd, H-aromatic C7, C13). Elemental analysis for $\mathrm{C}_{32} \mathrm{H}_{53} \mathrm{~N}_{5} \mathrm{O}_{4}$ : Found: C, 67.11; H, 9.18; N, 12.07, Calcd.: C, 67.22; H, 9.34; N, 12.25. [MALDI-TOF(+)-MS]: calcd for $\left(\mathrm{C}_{32} \mathrm{H}_{53} \mathrm{~N}_{5} \mathrm{O}_{4} \mathrm{Na}\right)\left\{[\mathrm{M}+\mathrm{Na}]^{+}\right\} \mathrm{m} / z$ 594.37, found $595.18(100 \%)$.

Synthesis of $\left[V^{V}{ }_{2} \mathrm{O}_{2}(\mu-\mathrm{O})(\alpha \text {-tocTHMA })_{2}\right], 1$. 1st Method: $\mathrm{V}^{\mathrm{IV}} \mathrm{OSO}_{4} \cdot 5 \mathrm{H}_{2} \mathrm{O}(0.13 \mathrm{~g}, 0.49 \mathrm{mmol})$ was stirred in $35 \mathrm{~mL} \mathrm{MeOH}$ at $35{ }^{\circ} \mathrm{C}$, under nitrogen. Then, $\mathrm{H}_{2} \alpha$-tocTHMA $(0.29 \mathrm{~g}$, $0.49 \mathrm{mmol})$ dissolved in the minimum amount of methanol, was added to the above methanolic solution resulting in a deep brown solution. The solution was stirred for $24 \mathrm{~h}$ at room temperature. Then, it was filtered to remove any precipitation, and the filtrate was kept at room temperature for 5 days. During that time a black solid of $\mathbf{1}$ was formed, which was filtered and dried under vacuum. The yield was $65 \mathrm{mg}, 20 \%$.

2nd Method: $\alpha$-tocTHMA $(1.2 \mathrm{~g}, 2.0 \mathrm{mmol})$ dissolved in the minimum amount of methanol was added to a stirring methanol solution $(40 \mathrm{~mL})$ of [ $\left.\mathrm{V}^{\mathrm{IV}} \mathrm{O}(\mathrm{acac})_{2}\right](0.53 \mathrm{~g}, 2.0 \mathrm{mmol})$ under nitrogen. The dark brown solution was stirring at room temperature for $10 \mathrm{~min}$. Then, the solution was filtered, and the filtrate was left unstirred for 5 days, under air, at room temperature. During that time a black solid of 1 was formed which was filtered and dried under vacuum. The yield was $0.35 \mathrm{~g}, 26 \%$. FTIR (ATR, $\left.\mathrm{cm}^{-1}\right)$ : $2924(\mathrm{C}-\mathrm{H}), 1580\left(\mathrm{C}=\mathrm{N}_{\text {triazine }}\right), 1524$ (ar C-C), $1094(\mathrm{~N}-\mathrm{O}), 966(\mathrm{~V}=\mathrm{O}), 798(\mathrm{~V}-\mathrm{O}-\mathrm{V})$. Elemental analysis for $\mathrm{C}_{68} \mathrm{H}_{110} \mathrm{~N}_{10} \mathrm{O}_{11} \mathrm{~V}_{2}$ : Found: $\mathrm{C}$, 60.47.11; H, 8.32; N, 10.10, Calcd.: C, 60.70; H, 8.24; N, 10.41. [MALDI-TOF(+)-MS]: calcd for $\left(\mathrm{C}_{34} \mathrm{H}_{55} \mathrm{~N}_{5} \mathrm{Na}_{2} \mathrm{O}_{6} \mathrm{~V}\right)\left\{[\mathrm{M}-\mathrm{O}-\mathrm{M}(-\mathrm{M}+2 \mathrm{Na})]^{+}\right\} \mathrm{m} / z$ 726.34, found $727.19(100 \%)$.

Synthesis of $\left[V^{V}{ }_{2} \mathrm{O}_{2}(\mu-O)(\delta \text {-tocTHMA) })_{2}\right], 2$. Similar with 1 synthetic methodologies were used for the synthesis of 2 . The yields were $24 \%$ and $19 \%$ for the 1 st and the 2 nd synthetic methods respectively. FTIR (ATR, $\left.\mathrm{cm}^{-1}\right): 2928(\mathrm{C}-\mathrm{H}), 1578\left(\mathrm{C}=\mathrm{N}_{\text {triazine }}\right), 1526$ (ar C-C), $1070(\mathrm{~N}-\mathrm{O}), 964(\mathrm{~V}=\mathrm{O}), 798(\mathrm{~V}-\mathrm{O}-\mathrm{V})$. Elemental analysis for $\mathrm{C}_{64} \mathrm{H}_{102} \mathrm{~N}_{10} \mathrm{O}_{11} \mathrm{~V}_{2}$ : Found: C, 59.45; H, 7.83; N, 10.47, Calcd.: C, 59.61; H, 7.97; N, 10.86. [MALDI-TOF(+)-MS]: calcd for $\left(\mathrm{C}_{32} \mathrm{H}_{52} \mathrm{~N}_{5} \mathrm{Na}_{2} \mathrm{O}_{6} \mathrm{~V}\right)\left\{[\mathrm{M}-\mathrm{O}-\mathrm{M}(-\mathrm{M}+2 \mathrm{Na})]^{+}\right\} \mathrm{m} / z$ 698.31, found $699.30(100 \%)$.

Synthesis of [Fe $e^{I I I}(\alpha$-tocTHMA)(H $\alpha$-tocTHMA)], 3. Ferric chloride $(0.03 \mathrm{~g}, 0.20 \mathrm{mmol})$ was dissolved under Ar in $20 \mathrm{~mL} \mathrm{MeOH}$ forming a yellow solution. $\mathrm{H}_{2} \alpha$-tocTHMA (0.24 g, $0.40 \mathrm{mmol}$ ) dissolved in the minimum amount of methanol was added in the above yellow solution, resulting in a deep blue solution. The solution was filtered, and the filtrate cooled at $-18{ }^{\circ} \mathrm{C}$ resulting in a black precipitate of 3 which was filtered and dried under vacuum. The yield was $120 \mathrm{mg}, 24 \%$. Elemental analysis for $\mathrm{C}_{68} \mathrm{H}_{111} \mathrm{FeN}_{10} \mathrm{O}_{8}$ : Found: $\mathrm{C}$, 65.11; H, 8.89; N, 10.95, Calcd.: C, 65.21; H, 8.93; N, 11.18. [MALDI-TOF(+)-MS]: calcd for $\left(\mathrm{C}_{34} \mathrm{H}_{55} \mathrm{~N}_{5} \mathrm{O}_{4} \mathrm{Fe}\right)\left\{[\mathrm{M}-\mathrm{L}]^{+}\right\} \mathrm{m} / z$ 653.36, found $654.31(100 \%)$.

Synthesis of $\left[\mathrm{Fe}^{I I I}(\delta\right.$-tocTHMA)(H $\delta$-tocTHMA)], 4. Complex 4 was synthesised using the same methodology as the one used for 3. The yield was $105 \mathrm{mg}, 22 \%$. Elemental analysis for $\mathrm{C}_{64} \mathrm{H}_{103} \mathrm{FeN}_{10} \mathrm{O}_{8}$ : Found: $\mathrm{C}, 64.09 ; \mathrm{H}, 8.81 ; \mathrm{N}, 11.69$, Calcd.: C, 64.25; H, 8.68; N, 11.71. [MALDI-TOF(+)-MS]: calcd for $\left(\mathrm{C}_{32} \mathrm{H}_{51} \mathrm{~N}_{5} \mathrm{O}_{4} \mathrm{Fe}\right)\left\{[\mathrm{M}-\mathrm{L}]^{+}\right\} \mathrm{m} / z$ 625.33, found 626.19 (100\%).

\subsection{Spectroscopic Studies}

All NMR samples were prepared from the dissolution of the solids in $\mathrm{CDCl}_{3}$ or $10 \%$ DMSO- $d_{6}: 90 \% \mathrm{D}_{2} \mathrm{O}$ at room temperature immediately before NMR spectrometric determinations. NMR spectra were recorded on a Bruker Avance 300 spectrometer at $300 \mathrm{MHz}$ for ${ }^{1} \mathrm{H}, 75.4 \mathrm{MHz}$ for ${ }^{13} \mathrm{C}$ and $78.9 \mathrm{MHz}$ for ${ }^{51} \mathrm{~V}$ NMR. A $30^{\circ}$-pulse width was applied for both the ${ }^{1} \mathrm{H}$ and ${ }^{51} \mathrm{~V}$ NMR measurements, and the spectra were acquired with 3000 and 30,000 Hz spectral window, using 1 and $0.1 \mathrm{~s}$ relaxation delay respectively. The spectra were analysed using Topspin 4.0 and MultispecNMR 5.0 (https:/ / sourceforge. net/projects/multispecnmr/, accessed on 1 March 2021). 2D [45] grNOESY spectra were obtained by using standard pulse sequences of Bruker Topspin 3.0 software. These spectra were acquired using 256 increments (with 56 scans each) and mixing time $0.43 \mathrm{~s}$.

UV-Vis measurements were recorded on a Photonics UV-Vis spectrophotometer Model 400, equipped with a CCD array, operating in the range 250 to $1000 \mathrm{~nm}$. The spectra were 
analysed using MultispecUVVIS 5.0 (https:/ / sourceforge.net/projects/multispecuvvis/, accessed on 1 March 2021).

\subsection{Reactivity with $D P P H^{\bullet}$}

The rate of DPPH ${ }^{\bullet}$ consumption was measured by UV-vis spectroscopy at $520 \mathrm{~nm}$ for $30 \mathrm{~min}$. Stock solutions of each compound $(12 \mathrm{mM})$ were prepared in dry toluene at room temperature. The final concentrations of the compounds were 80-300 $\mu \mathrm{M}$, while the concentration of $\mathrm{DPPH}^{\bullet}$ was $100 \mu \mathrm{M}$. The samples were incubated at $25^{\circ} \mathrm{C}$ for $4 \mathrm{~min}$. The reaction was initiated by the addition of the $\mathrm{DPPH}^{\bullet}$ solution. The samples were measured in triplicate. Second-order rate constants were calculated to determine the radical scavenging activity (RSC) of antioxidants. The decay of $\mathrm{DPPH}^{\bullet}$ from the medium has been assumed to follow pseudo-first-order kinetics, under the conditions of the reaction $\left[\mathrm{DPPH}^{\bullet}\right]_{0},[\mathrm{AH}]_{0}$. One of the reactants is in large excess compared to the other, so the concentration of the minor component decreased exponentially [46]. The [DPPH ${ }^{\bullet}$ ] concentration is calculated from Equation (1):

$$
\left[\mathrm{DPPH}^{\bullet}\right]=\left[\mathrm{DPPH}^{\bullet}\right]_{0} \mathrm{e}^{-k \text { obsd } t}
$$

where $\left[\mathrm{DPPH}^{\bullet}\right]$ is the radical concentration at time $t$, and $\left[\mathrm{DPPH}^{\bullet}\right]_{0}$ is the radical concentration at time zero, and $k_{\text {obsd }}$ is the pseudo-first-order rate constant. The pseudo-first-order rate constant $k_{\text {obsd }}$ was linearly dependent on the concentration of antioxidants [AH], and from the slope of their plot, second-order rate constants $\left(k_{2}\right)$ were calculated to evaluate the radical scavenging capacity of each compound.

\subsection{Measurement of Oxidative Inducing Effect of Vanadium Compounds by EPR Spectroscopy}

An ELEXSYS E500 Bruker EPR spectrometer operating at cw X-band, resonance frequency $\sim 9.5 \mathrm{GHz}$ and modulation frequency $100 \mathrm{MHz}$ was used. The resonance frequency was accurately measured with solid DPPH $(g=2.0036)$. The EPR oxidative inducing effect experiments were conducted by monitoring the evolution of $\alpha$-tocopheryl radicals versus time [37] at room temperature. The assays were prepared in a $5 \mathrm{~mm}$ quartz tube by adding $100 \mu \mathrm{L}$ or $150 \mu \mathrm{L}$ of a $\mathrm{CHCl}_{3}$ stock solution $(4.95 \mathrm{mM})$ of complex to $0.500 \mathrm{~g}$ of a commercial extra virgin olive oil. Radical initiators are the $\mathbf{1}, \mathbf{2}$ and [VO(C18DEA)] whereas the addition step consists of the initial time of the reaction, time $=0 \mathrm{~min}$. EPR spectra were recorded for 25- or 30-time domains, each one consisting of 50 scans. The spectra were processed using appropriate software, MultispecEPR 5.0 (https:/ /sourceforge.net/projects/multispecepr/, accessed on 1 March 2021).

\subsection{Cell Culture}

The human tongue squamous cell carcinoma (Cal33, DSMZ ${ }^{\circledR}$ ACC 447), the human cell line derived from cervical cancer (HeLa, ATCC ${ }^{\circledR} \mathrm{CCL}-2$ ) and the embryonic mouse fibroblasts (NIH/3T3, CRL-1658 ${ }^{\mathrm{TM}}$ ) were used in this study [47]. Cells were grown in monolayer cultures in high glucose Dulbecco's modified eagle medium (DMEM) supplemented with $10 \%(v / v)$ foetal bovine serum, $2 \mathrm{mM}$ L-glutamine and $1 \%(v / v)$ penicillin-streptomycin (100×: 10,000 units/mL of penicillin and $10,000 \mu \mathrm{g} / \mathrm{mL}$ streptomycin) in a humidified incubator $\left(5 \% \mathrm{CO}_{2}, 95 \%\right.$ air $)$ at $37^{\circ} \mathrm{C}$.

\subsection{Measurement of Cell Viability}

Cells were plated in 96-well plates at density $5 \times 10^{3}$ cells/well and treated with the ligands or the complexes for 24 and $48 \mathrm{~h}$. Cell viability was measured after incubation of each well with $50 \mu \mathrm{L}$ of MTT (stock solution of $3 \mathrm{mg} / \mathrm{mL}$ ) for $3 \mathrm{~h}$ and absorbance was determined at $570 \mathrm{~nm}$ (background absorbance measured at $690 \mathrm{~nm}$ ) using a microplate spectrophotometer (Multiskan Spectrum, Therno Fisher Scientific, Waltham, MA, USA). All experiments were performed in triplicate.

Stock solutions of $\mathrm{H}_{2} \alpha$-tocTHMA and $\mathrm{H}_{2} \delta$-tocTHMA and 1-4 prepared in pure DMSO were diluted into the culture medium so that the final concentration of DMSO was less 
than $1 \%$. The same amount of DMSO was added to the control sample. Stock solutions were kept at $4{ }^{\circ} \mathrm{C}$.

\section{Results and Discussion}

\subsection{Synthesis and Characterisation}

The triazine tocopherol molecules $\mathrm{H}_{2} \alpha$-tocTHMA and $\mathrm{H}_{2} \delta$-tocTHMA were synthesized by two-step substitution reactions of cyanuric chloride. The synthetic process is summarised in Scheme 2.

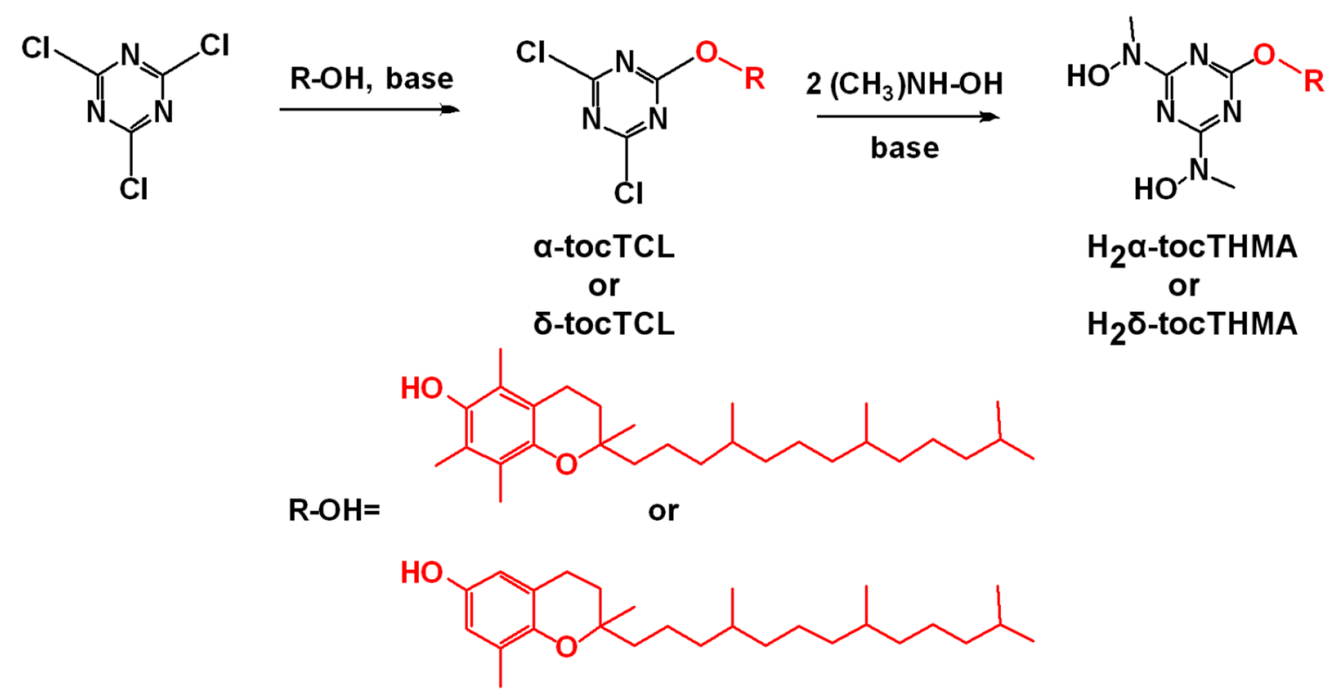

Scheme 2. Synthetic route for the organic compounds.

Reaction of equimolar quantities of $\mathrm{H}_{2} \alpha$-tocTHMA or $\mathrm{H}_{2} \delta$-tocTHMA with [V ${ }^{\mathrm{IV}} \mathrm{O}(\text { acac })_{2}$ ] or $\mathrm{V}^{\mathrm{IV}} \mathrm{OSO}_{4}$ results in the formation of $\mathrm{V}^{\mathrm{V}}$ complexes $\mathbf{1}$ and $\mathbf{2}$ (Scheme 3). The $\mathrm{V}^{\mathrm{IV}}$ is oxidised to $\mathrm{V}^{\mathrm{V}}$ by the atmospheric $\mathrm{O}_{2}$. X-band EPR spectroscopy of frozen $\mathrm{CHCl}_{3}$ solutions of either $\mathbf{1}$ or $\mathbf{2}$ did not exhibit any signal supporting that all $\mathrm{V}^{\mathrm{IV}}$ has been oxidised to $\mathrm{V}^{\mathrm{V}}$.<smiles>[R]Oc1nc(N(C)O)nc(N(C)O)n1</smiles><smiles>Cc1c(C)c2c(c(C)c1O)CCC(C)(CCCC(C)CCCC(C)CCCC(C)C)O2</smiles><smiles>Cc1cc(O)cc2c1OC(C)(CCCC(C)CCCC(C)CCCC(C)C)CC2</smiles>

Scheme 3. Synthetic route for the vanadium complexes. 
The complexes were characterised by elemental analysis, UV-vis, IR and NMR spectroscopies. The structures of the vanadium complexes are based on the data of the experimental analysis and the $\mathrm{X}$-ray structures of the respective $\mathrm{V}^{\mathrm{V}}$-bihyat ${ }^{2-}$ complexes [42].

\subsection{Complexes Characterisation by IR}

The IR spectra of $\mathbf{1}$ and $\mathbf{2}$ are shown in Figure 1 . Both $\mathbf{1}$ and $\mathbf{2}$ gave a strong peak at $966 \mathrm{~cm}^{-1}$ attributed to the stretching of the $\mathrm{V}=\mathrm{O}$ bond. The peaks at $798 \mathrm{~cm}^{-1}$ are characteristic to $\mathrm{V}-\mathrm{O}-\mathrm{V}$ stretching vibrations $[48,49]$, thus, confirming the dinuclear structure of the complex. The complexes also show two strong stretching N-O vibrations shifted around $80 \mathrm{~cm}^{-1}$ at higher energy compared to the free ligand suggesting coordination of the metal ion from the hydroxylamine-triazine chelating group.

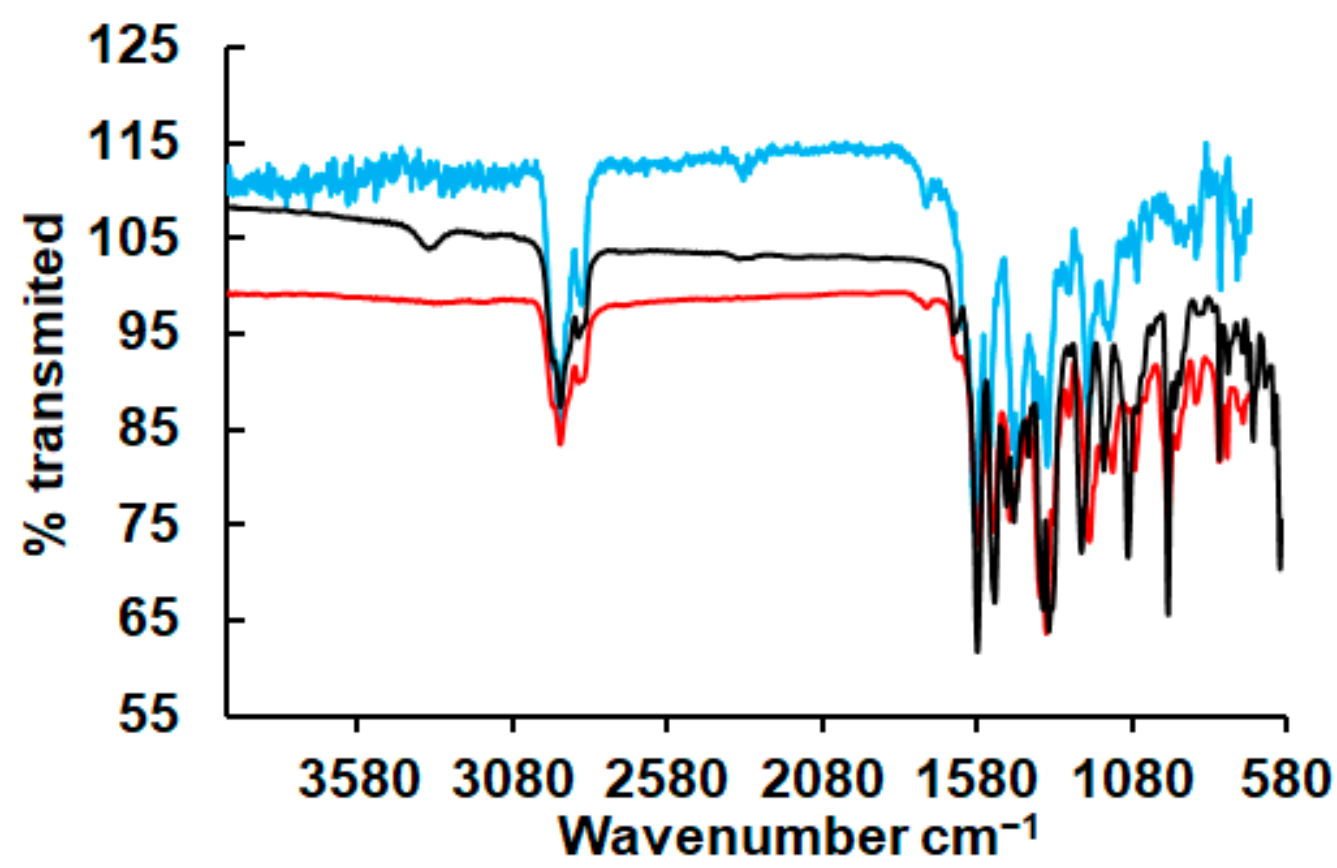

Figure 1. IR spectra of: $1\left[v\left(V=O, 966 \mathrm{~cm}^{-1}\right.\right.$; (C=N triazine $), 1579,1529 \mathrm{~cm}^{-1} ;(\mathrm{Ph}-\mathrm{O}), 1242 \mathrm{~cm}^{-1}$; (N-O), $\left.1092 \mathrm{~cm}^{-1}\right] ; 798$ (V-O-V)] (black line), 2 [v(V=O, $966 \mathrm{~cm}^{-1}$; (C=N triazine), 1579, $1529 \mathrm{~cm}^{-1}$; (Ph-O), $1240 \mathrm{~cm}^{-1}$; (N-O), $1084 \mathrm{~cm}^{-1}$ ]; 798 (V-O-V) (red line), 3 [(C=N triazine), 1569, $1525 \mathrm{~cm}^{-1}$; (Ph-O), $1244 \mathrm{~cm}^{-1}$; (N-O), $1093 \mathrm{~cm}^{-1}$ ] (blue line).

The IR spectra of the complexes 3 and 4 gave peaks at 2952, 2924 and $2896 \mathrm{~cm}^{-1}$ assigned to the $\mathrm{C}-\mathrm{H}$ stretching of lipid chains. The $\mathrm{C}=\mathrm{N}$ ring vibrations show peaks at 1569 and $1525 \mathrm{~cm}^{-1}$ whereas Ph-O and N-O stretching vibrations were detected at 1244 and $1093 \mathrm{~cm}^{-1}$ respectively. The N-O peaks are significantly shifted compared to the free ligand $\left(\sim 70 \mathrm{~cm}^{-1}\right)$ due to the ligation of the ligand to $\mathrm{Fe}^{\mathrm{III}}$.

\subsection{Complex Characterisation by ${ }^{51} V N M R, 2 D\left\{{ }^{1} H\right\}$ grNOESY}

The ${ }^{51} \mathrm{~V}$ spectra of each of the $\mathrm{V}^{\mathrm{V}}$ complexes $(\mathbf{1}, \mathbf{2})$ in $\mathrm{CDCl}_{3}$ solutions gave two signals at -216 and -387 ppm (Figure 2). The intensity of the peaks is dependent on the concentration of the complexes in solution. At low concentration (i.e., $1 \mathrm{mM}$ ) the component at $-216 \mathrm{ppm}$ is the major, whereas at more concentrate solutions (i.e., $7 \mathrm{mM}$ ) the spectra of each of the complexes shows only the peak at $-387 \mathrm{ppm}$. For more concentrated solutions three broad additional peaks of equal intensity appear at higher field $(-402,-439$ and $-648 \mathrm{ppm}$ ), presumably originated from a higher nuclearity compound. The ${ }^{51} \mathrm{~V}$ NMR spectra changes observed by the variation of the concentration are attributed to the equilibrium between the monomer (1m), dimer (1) and oligomers (Scheme 4 ). The quantities of $\mathbf{1 m}$ and 1 are equal at concentration $2.5 \mathrm{mM}$, calculating a $\mathrm{K}_{\mathrm{eq}}=\left[\mathbf{1 m}^{2}\right] /[1]=1.25 \times 10^{-3} \mathrm{M}$. The conversion of the $\mathbf{1}$ to $\mathbf{1 m}$ species takes approximately $2 \mathrm{~min}$ after the dissolution 
of $\mathbf{1}$ in $\mathrm{CDCl}_{3}$, and it can be observed by the change of the colour of the solution from purple to blue. Dimerization of the hydroxylamine-triazine ligands through the formation of M-O-M bridge has been previously observed for $\mathrm{U}^{\mathrm{VI}}-, \mathrm{Mo}^{\mathrm{VI}}$ - and $\mathrm{V}^{\mathrm{V}}$-bihyat ${ }^{2-}$ complexes $[42,43]$. The respective ${ }^{51} \mathrm{~V}$ NMR spectrum of $\mathrm{CDCl}_{3}$ solution of the structurally characterised by single crystal X-ray dinuclear complex $\left[\mathrm{VV}_{2} \mathrm{O}_{2}\left(\mu_{2}-\mathrm{O}\right)(\text { bihyat })_{2}\right]$ exhibits peaks at $-192,-402$ and $-485 \mathrm{ppm}$. However, the ${ }^{51} \mathrm{~V}$ NMR peaks of the $\mathrm{CDCl}_{3}$ solution of $\left[\mathrm{V}_{2} \mathrm{O}_{2}\left(\mu_{2}-\mathrm{O}\right)(\text { bihyat })_{2}\right]$ at $-192 \mathrm{ppm}$ had been mistakenly attributed to the decomposition of the compound.

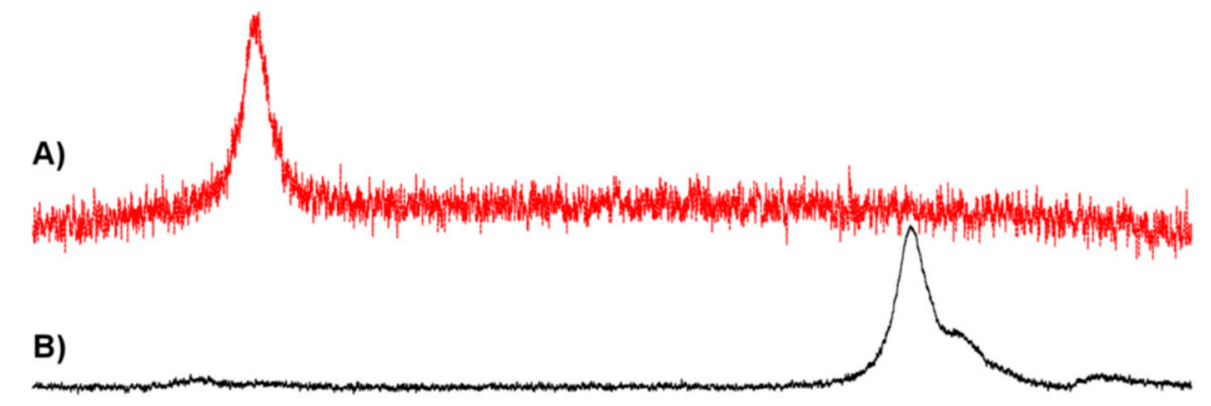

$\begin{array}{cccccc}-160 & -220 & -280 & -340 & -400 & -460 \\ \text { ppm } & \end{array}$

Figure 2. ${ }^{51} \mathrm{~V}$ NMR spectra of $\mathrm{CD}_{3} \mathrm{Cl}$ solutions of 1, (A) $1.00 \mathrm{mM}$ (B) $7.00 \mathrm{mM}$.

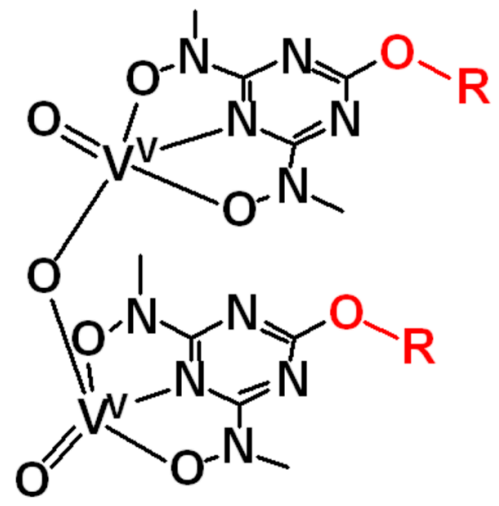

1
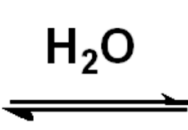

$1 \mathrm{~m}$

Scheme 4. Equilibrium between the monomer, $1 \mathrm{~m}$ and the dimer, $\mathbf{1}$.

The 2D $\left\{{ }^{1} \mathrm{H}\right\}$ grNOESY of $\mathbf{1}$ is shown in Figure 3. The two methyl groups show difference in chemical shifts due to the different chemical environment. $2 \mathrm{D}\left\{{ }^{1} \mathrm{H}\right\}$ grNOESY shows positive cross peaks between the protons of the two methyl groups assigned to the slow rotation methylhydroxylamine giving two peaks at 2.869 and $2.573 \mathrm{ppm}$ in proton NMR. The rotation of tocopherol is performed around the ether bond between tocopherol and triazine moieties (Figure 3). 


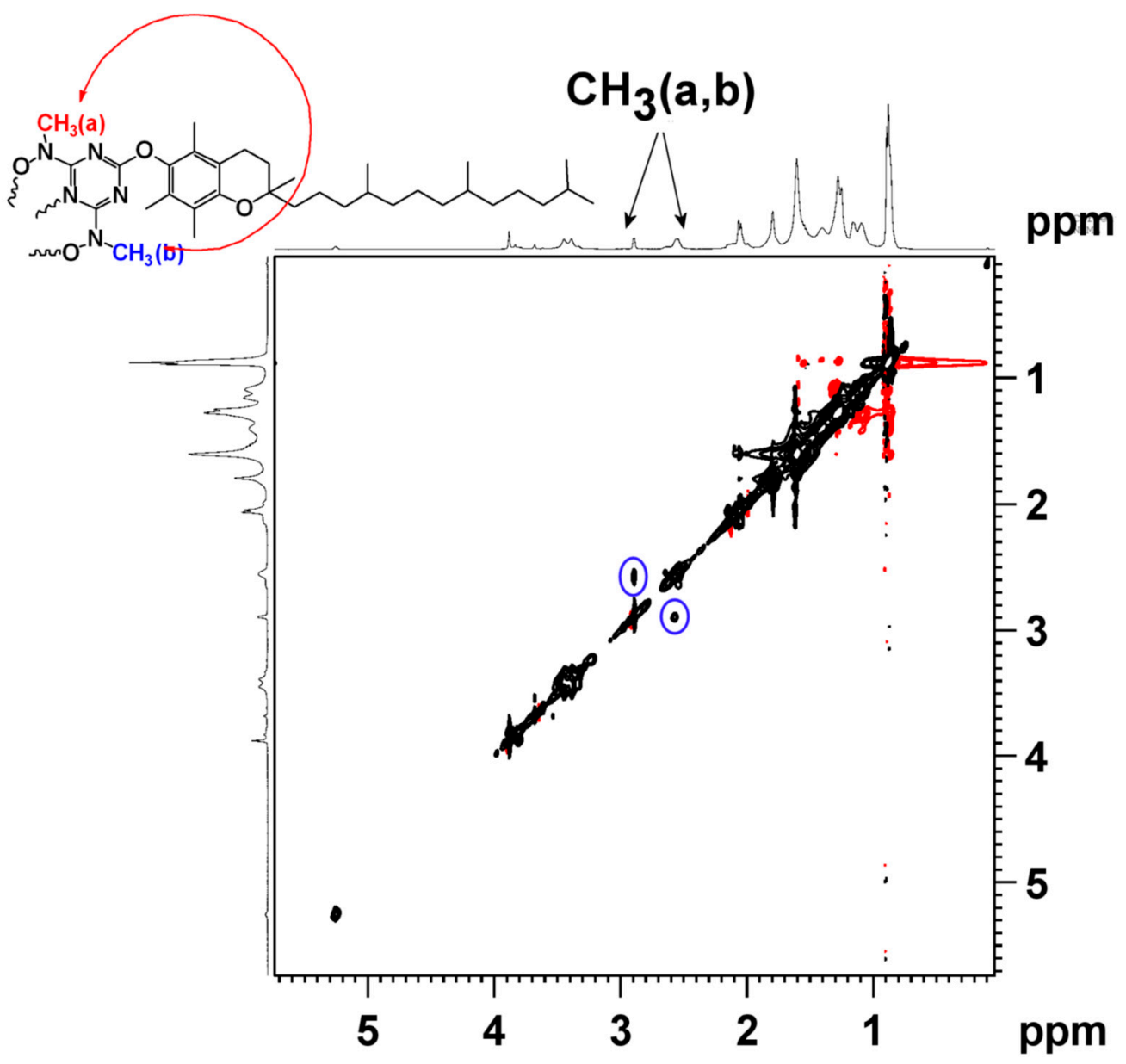

Figure 3. 2D $\left\{{ }^{1} \mathrm{H}\right\}$ grNOESY spectrum of $\mathrm{CDCl}_{3}$ solution of $\mathbf{1}(1.00 \mathrm{mM})$. Exchange of $\mathrm{CH}_{3}(\mathrm{a})$ and $\mathrm{CH}_{3}(\mathrm{~b})$ cross peaks in blue circles.

\subsection{Complexes Characterisation by UV-Vis}

The UV-vis spectra of the $\mathrm{CHCl}_{3}$ solutions of $\mathbf{1}$ and $\mathbf{2}$ are shown in Figure 4. Both gave strong peaks in the visible region $\left[\lambda(\varepsilon)\right.$ of $1=493 \mathrm{~nm}\left(3600 \mathrm{M}^{-1} \mathrm{~cm}^{-1}\right), 682 \mathrm{~nm}\left(1140 \mathrm{M}^{-1} \mathrm{~cm}^{-1}\right)$, $\lambda(\varepsilon)$ of $\left.2=484 \mathrm{~nm}\left(2300 \mathrm{M}^{-1} \mathrm{~cm}^{-1}\right), 645 \mathrm{~nm}\left(860 \mathrm{M}^{-1} \mathrm{~cm}^{-1}\right)\right]$ assigned to the ligand to metal charge transfer transitions (LMCT). The concentration of the complexes in solutions were $0.500 \mathrm{mM}$, and according to ${ }^{51} \mathrm{~V}$ NMR the species in the solution have the monomeric structure, $1 \mathrm{~m}$ and $\mathbf{2 m}$ (Scheme 4). Although $\left[\mathrm{V}^{\mathrm{V}} \mathrm{O}_{2} \text { (bihyat) }\right]^{-}$has a similar structure with the monomers $1 \mathrm{~m}$ and $\mathbf{2 m}$, it does not exhibit any strong absorption peaks in the visible region. Thus, the strong colour of $1 \mathrm{~m}$ and $\mathbf{2 m}$ is due to electron transitions from the chromanol ring to the metal. Chromanol ring can contribute electronically to the metal ion through the resonance of the triazine ring (Scheme 5) [42]. The shift of the UV-vis peaks of $\mathbf{1}$ to lower energy compared to those of $\mathbf{2}$ agrees with the higher electron density of $\alpha$ - than $\delta$-tocopherol, supporting our hypothesis regarding the significance of the chromanol role on the LMCT effect. 


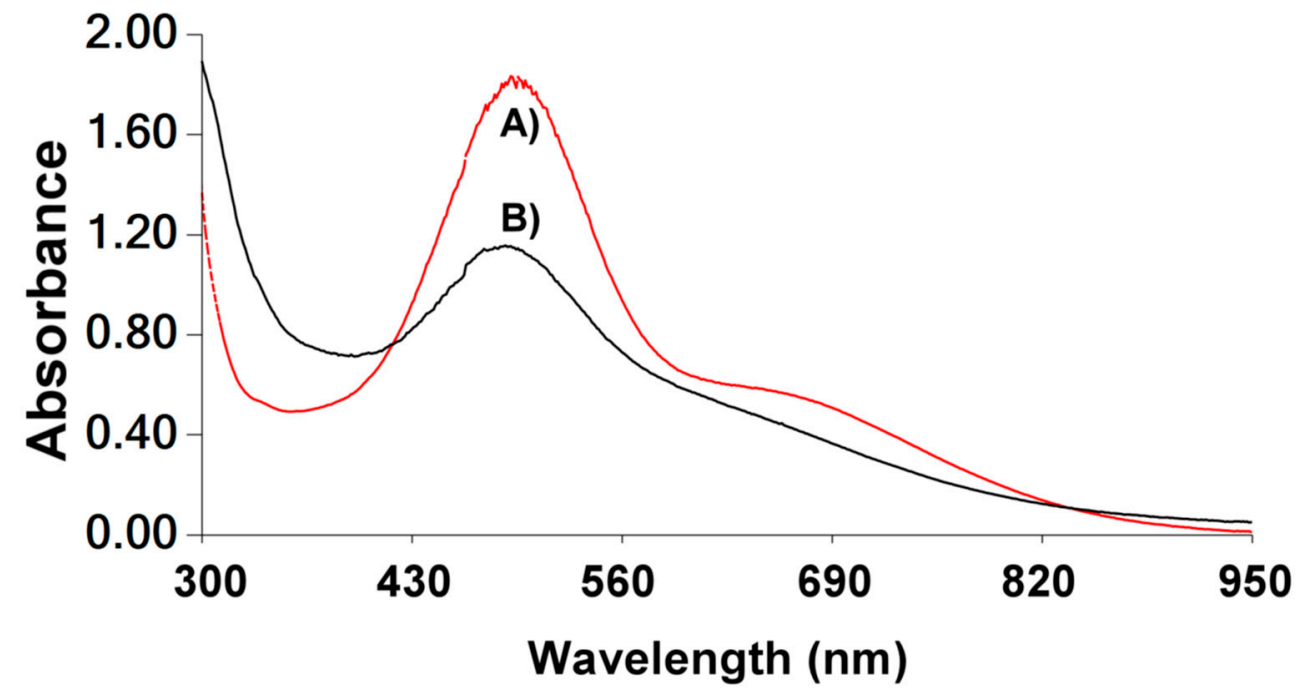

Figure 4. UV-vis spectra of $\mathrm{CHCl}_{3}$ solutions of $0.500 \mathrm{mM}$ of $(\mathbf{A}) \mathbf{1 m}\left[\lambda(\varepsilon)=493 \mathrm{~nm}\left(3600 \mathrm{M}^{-1} \mathrm{~cm}^{-1}\right)\right.$, $\left.682 \mathrm{~nm}\left(1140 \mathrm{M}^{-1} \mathrm{~cm}^{-1}\right)\right]$ and (B) $2 \mathrm{~m}\left[\lambda(\varepsilon)=484 \mathrm{~nm}\left(2300 \mathrm{M}^{-1} \mathrm{~cm}^{-1}\right), 645 \mathrm{~nm}\left(860 \mathrm{M}^{-1} \mathrm{~cm}^{-1}\right)\right]$.<smiles>[R]Oc1nc(N(C)O)nc(N(C)O)n1</smiles><smiles>[R][O+]=C1[C-]NC(=[N+](C)O)[C+]([N+](C)=O)N1</smiles>

\section{$\mathrm{R}-\mathrm{OH}=$}<smiles>Cc1c(C)c2c(c(C)c1O)CCC(C)(CCCC(C)CCCC(C)CCCC(C)C)O2</smiles><smiles>Cc1cc(O)cc2c1OC(C)(CCCC(C)CCCC(C)CCCC(C)C)CC2</smiles>

Scheme 5. Triazine resonance structures.

The $\mathrm{CHCl}_{3}$ solutions of Fe $\mathrm{FII}^{\mathrm{III}}$ complexes 3 and 4 gave peaks at $560 \mathrm{~nm}\left(3200 \mathrm{M}^{-1} \mathrm{~cm}^{-1}\right)$ and $535 \mathrm{~nm}\left(2200 \mathrm{M}^{-1} \mathrm{~cm}^{-1}\right)$ respectively (Figure 5A). These spectra are similar to other hydroxylamine-triazin iron complexes, for example the $\mathrm{Fe}^{\mathrm{III}}$-bihyat compounds [41]. Complexes 3 and 4 exhibit the same pattern as the vanadate complexes; the $\alpha$-tocopherol complex 3 absorbs at lower energy than the $\delta$-tocopherol complex 4 . This is in line with the proposed electron transfer resonance mechanism proposed in Scheme 5. 


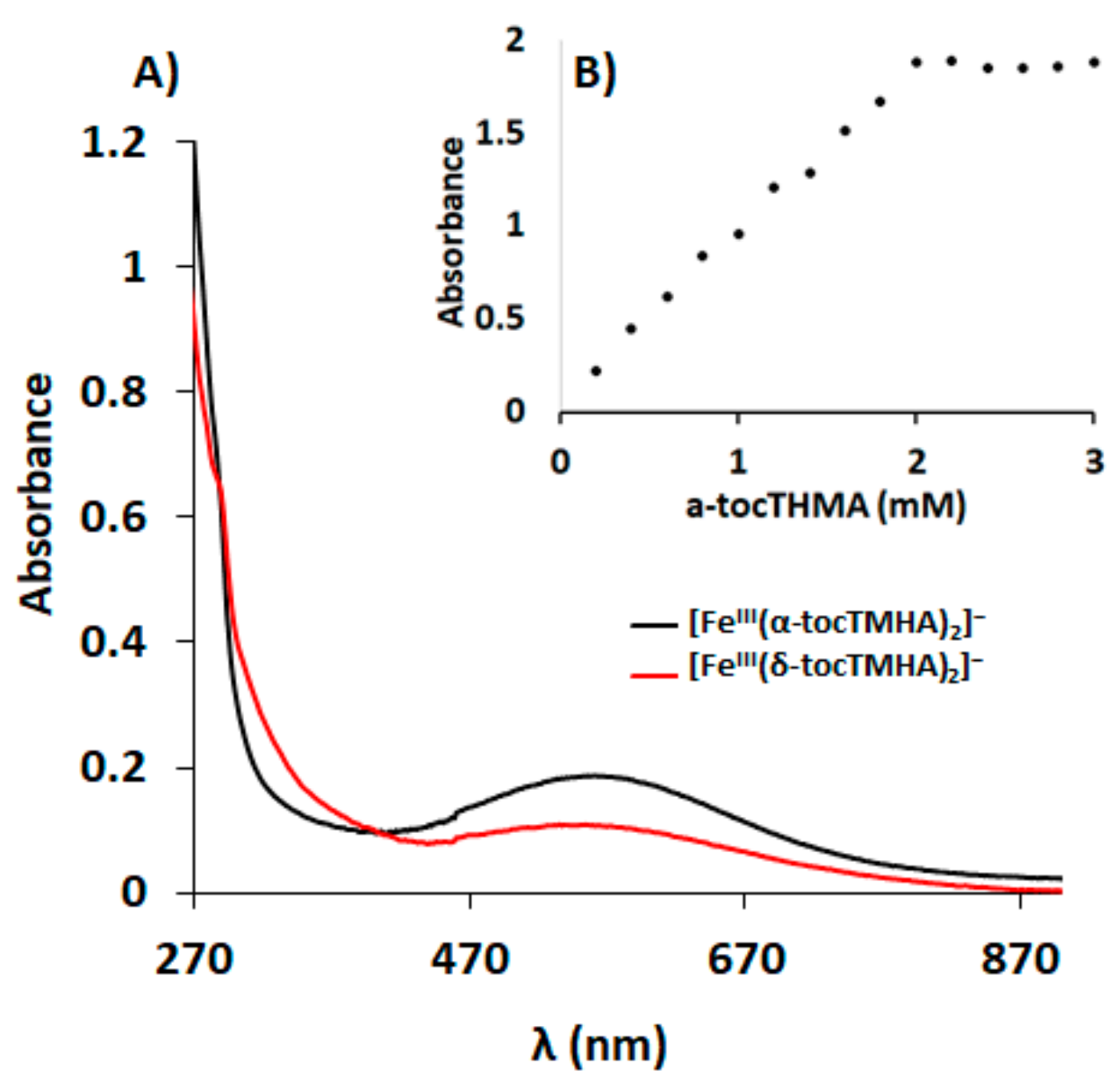

Figure 5. (A) UV-vis spectra of $\mathrm{CHCl}_{3}$ solutions of $0.100 \mathrm{mM}$ of 3 [black line, $\lambda(\varepsilon)=560 \mathrm{~nm}$ $\left(3200 \mathrm{M}^{-1} \mathrm{~cm}^{-1}\right)$ ] and 4 [red line, $\lambda(\varepsilon)=535 \mathrm{~nm}\left(2200 \mathrm{M}^{-1} \mathrm{~cm}^{-1}\right)$ ]. (B) Absorbance at $560 \mathrm{~nm}$ vs. the concentration of $a$-tocTMHA added in the $\mathrm{CHCl}_{3}$ solution of $\mathrm{FeCl}_{3}(1.00 \mathrm{mM})$.

Addition of various quantities of either $\mathrm{H}_{2} \alpha$-tocTHMA or $\mathrm{H}_{2} \delta$-tocTHMA to a $\mathrm{CHCl}_{3}$ solution of $\mathrm{Fe}^{\mathrm{III}} \mathrm{Cl}_{3}$ gave the same spectra with 3 and 4 respectively. Titration of the $\mathrm{CHCl}_{3}$ solution of $\mathrm{Fe}^{\mathrm{III}} \mathrm{Cl}_{3}$ with either $\mathrm{H}_{2} \alpha$-tocTHMA (Figure $5 \mathrm{~B}$ ) or $\mathrm{H}_{2} \delta$-tocTHMA reveal that only the 1:2 Fe $\mathrm{III}^{\mathrm{II}}$-Ligand complexes are formed in the solution.

\subsection{Characterisation of the Complexes in 10\% DMSO:90\% $\mathrm{D}_{2} \mathrm{O}$ Solutions by ${ }^{51} \mathrm{~V} \mathrm{NMR}$}

The ${ }^{51} \mathrm{~V}$ NMR spectra of $10 \%$ DMSO:90\% $\mathrm{D}_{2} \mathrm{O}$ solutions of inorganic vanadate with either 1 or 2 at $\mathrm{pD}=5.0-7.5$ clearly shows very different chemical shifts for the peaks of vanadate oligomers from those of the complexes, undoubtedly assigning the peaks at $-560 \mathrm{ppm}$ to the new vanadium complexes (Figures 6 and 7). The addition of $\mathrm{D}_{2} \mathrm{O}$ in the DMSO solutions ( $10 \%$ DMSO:90\% $\left.\mathrm{D}_{2} \mathrm{O}, \mathrm{pD}=6.0-7.5\right)$ of 1 or 2 at concentrations $0.10 \mathrm{mM}$ do not hydrolyse the complexes as evidenced by the ${ }^{51} \mathrm{~V}$ NMR spectroscopy (the spectra show only one peak originated from the complex and there is no formation of any inorganic vanadate species (Figure 6)). In the ${ }^{51} \mathrm{~V} \mathrm{NMR} \mathrm{spectra,} \mathrm{a} \mathrm{shift} \mathrm{from}-387 \mathrm{ppm}$ in $\mathrm{CDCl}_{3}$ to $-560 \mathrm{ppm}$ in 10\% DMSO:90\% $\mathrm{D}_{2} \mathrm{O}$ observed for 1 originated from the structural change of the complex from tetragonal pyramidal to dioxido octahedral geometry. A similar shift was observed upon changing from $\mathrm{CDCl}_{3}$ to $\mathrm{D}_{2} \mathrm{O}$ solutions for $\left[\mathrm{VO}_{2} \text { (bihyat) }\right]^{-}$as well [42]. The 10\% DMSO:90\% $\mathrm{D}_{2} \mathrm{O}$ solutions of 1 or 2 were stable at these conditions for more than $72 \mathrm{~h}$. The high hydrolytic stability of $\mathbf{1}$ and $\mathbf{2}$ is attributed to their amphiphilic nature [36,38,39]. The lipophilicity of $\mathbf{1}$ and $\mathbf{2}$ may enhance the hydrolytic stabilisation over the non-lipophilic vanadium complexes, exhibiting the same coordination environment, through a more favourable solvation [40]. 


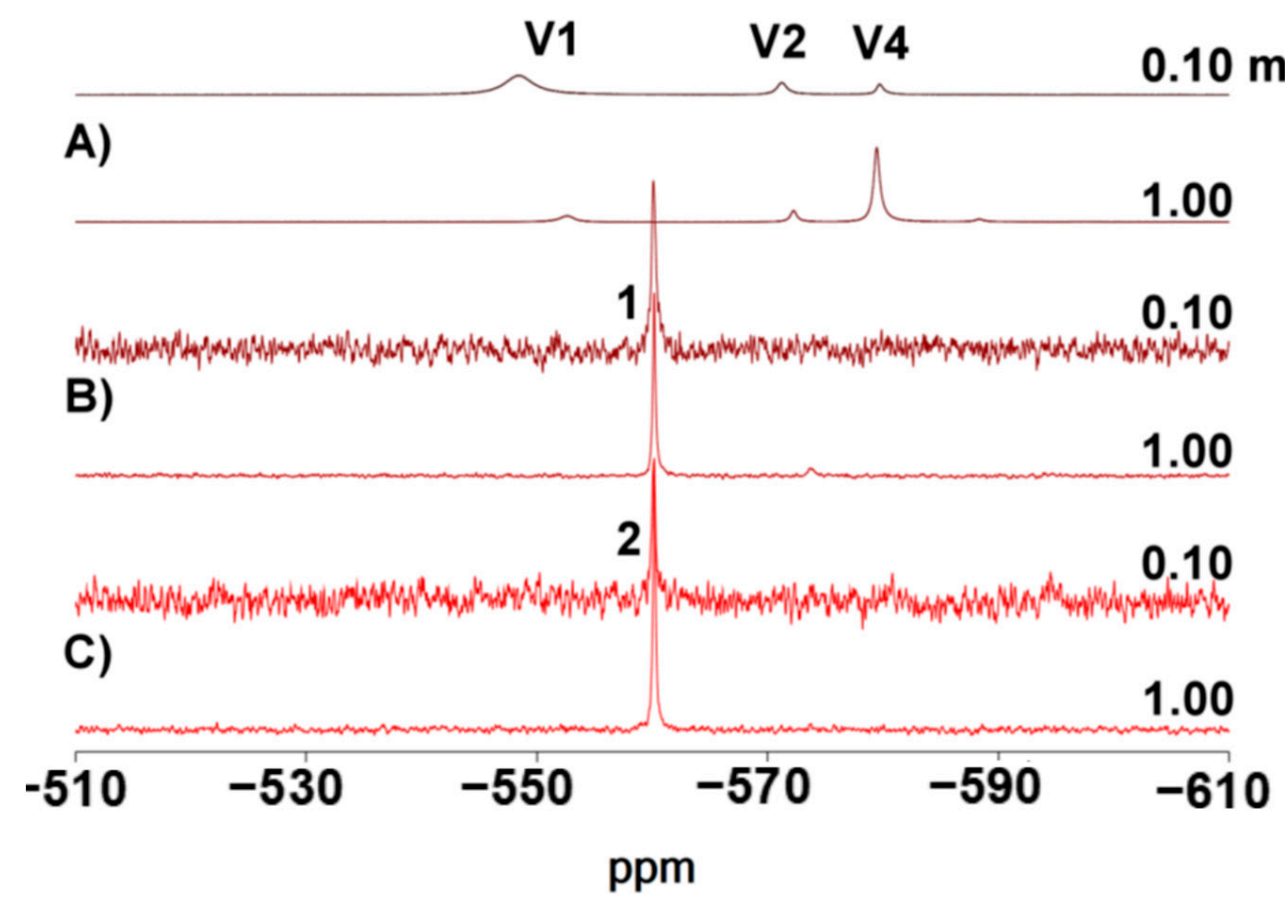

Figure 6. ${ }^{51} \mathrm{~V}$ NMR spectra DMSO- $d_{6}: \mathrm{D}_{2} \mathrm{O}(1: 9)$ solutions of $(\mathbf{A}) \mathrm{NaVO}_{3}$, (B) 1, (C) 2 at $\mathrm{pD} \sim 7$. V1, $\mathrm{V} 2, \mathrm{~V} 4$ are the vanadium oligomers.

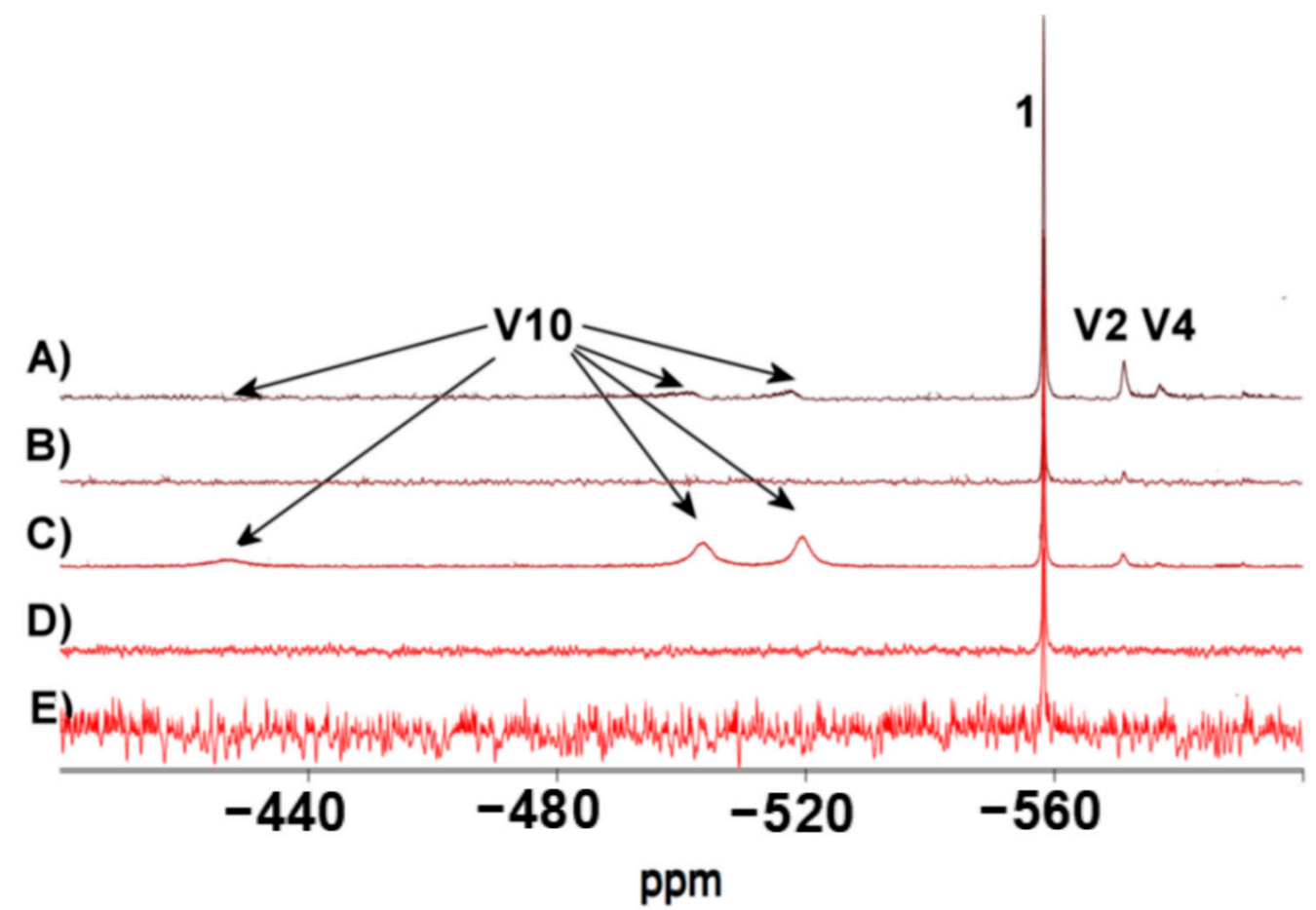

Figure 7. ${ }^{51} \mathrm{~V}$ NMR spectra DMSO- $d_{6}: \mathrm{D}_{2} \mathrm{O}(1: 9)$ solutions of $(\mathbf{A}) 1.00 \mathrm{mM}$ of $\mathbf{1}+1.00 \mathrm{mM} \mathrm{NaVO}_{3}$, $\mathrm{pD}=5.9$ (B) $1.00 \mathrm{mM}$ of $\mathbf{1} \mathrm{pD}=5.9$ (C) $1.00 \mathrm{mM}$ of $\mathbf{1}+1.00 \mathrm{mM} \mathrm{NaVO}_{3}, \mathrm{pD}=5.0$ (D) $1.00 \mathrm{mM}$ of $\mathbf{1}$, $\mathrm{pD}=5.0$. (E) $0.10 \mathrm{mM}$ of $\mathbf{1}, \mathrm{pD}=7.0$. V10, V2, V4 are the vanadium oligomers.

3.6. Characterisation of the Complexes in 10\% DMSO:90\% $\mathrm{D}_{2} \mathrm{O}$ Solutions by UV-Vis Spectroscopy

The UV-vis spectra of the $10 \% \mathrm{DMSO}$ : $90 \% \mathrm{D}_{2} \mathrm{O}$ solutions of $\mathbf{1}$ and $\mathbf{2}$ were similar to the spectra of the complexes in $\mathrm{CHCl}_{3}$ (Figure 8). The only difference between the spectra in the two different solvents is the lower intensity of the peaks in $10 \% \mathrm{DMSO}: 90 \% \mathrm{D}_{2} \mathrm{O}$ than $\mathrm{CHCl}_{3}$. However, complexes $\mathbf{1}$ and $\mathbf{2}$ show significant different absorption coefficients 
compared to those of $\left[\mathrm{VO}_{2} \text { (bihyat) }\right]^{-}$in various solvents [42]. The extinction coefficients of 1 and 2 are lower in protic polar solvents than in the non-polar ones in the same manner as $\left[\mathrm{VO}_{2} \text { (bihyat) }\right]^{-}$. The absorbance values from the UV spectra of $\mathbf{1}, \mathbf{2}$ solutions appear to obey Beer's law, even at low concentrations at $50 \mu \mathrm{M}$, suggesting that the complexes are hydrolytically stable in those solutions (Figure 9), in agreement with ${ }^{51} \mathrm{~V}$ NMR spectroscopy. The spectra of the $10 \%$ DMSO: $90 \% \mathrm{D}_{2} \mathrm{O}$ solutions of the iron complexes 3 and 4 are also similar with their spectra in $\mathrm{CHCl}_{3}$ solutions.

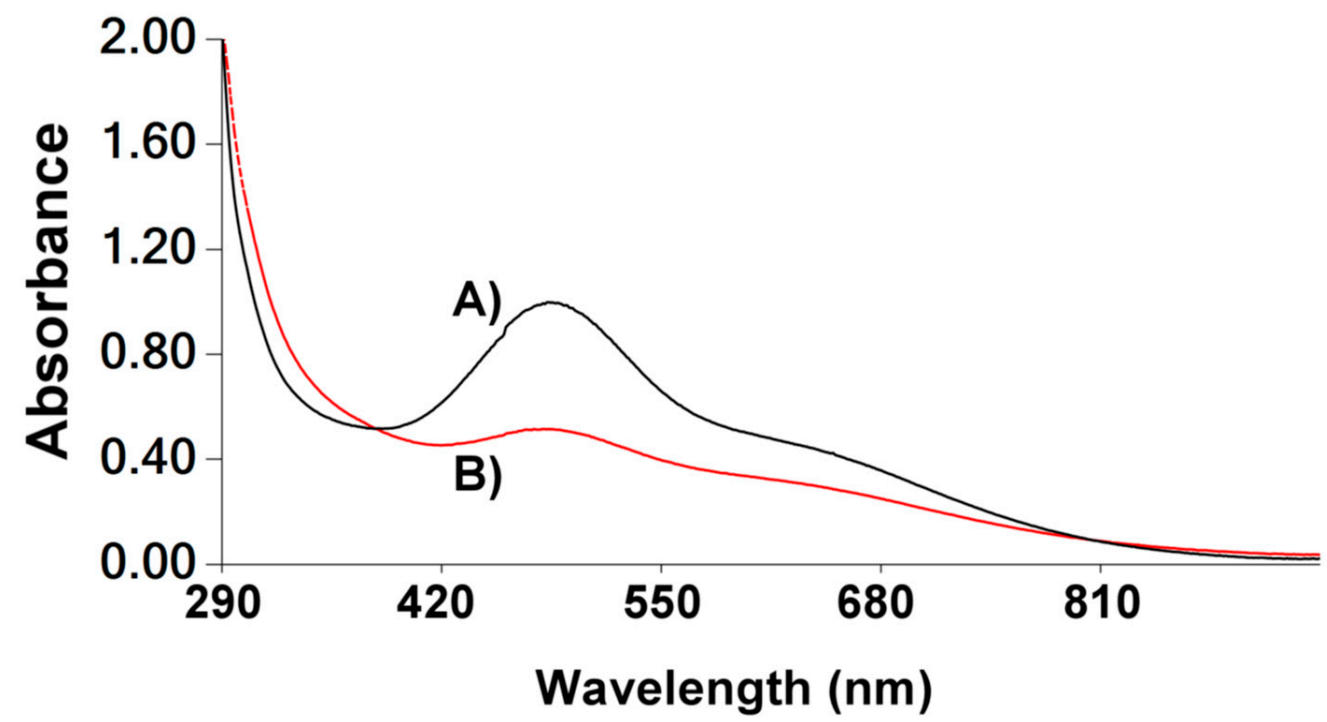

Figure 8. UV-vis spectra of DMSO- $d_{6}: \mathrm{D}_{2} \mathrm{O}(1: 9)$ solutions of $0.500 \mathrm{mM}$ of (A) $1[\lambda(\varepsilon)=490 \mathrm{~nm}$ $\left.\left(2000 \mathrm{M}^{-1} \mathrm{~cm}^{-1}\right), 675 \mathrm{~nm}\left(900 \mathrm{M}^{-1} \mathrm{~cm}^{-1}\right)\right]$ and (B) $2\left[\lambda(\varepsilon)=490 \mathrm{~nm}\left(1100 \mathrm{M}^{-1} \mathrm{~cm}^{-1}\right), 675 \mathrm{~nm}\right.$ $\left.\left(660 \mathrm{M}^{-1} \mathrm{~cm}^{-1}\right)\right]$.

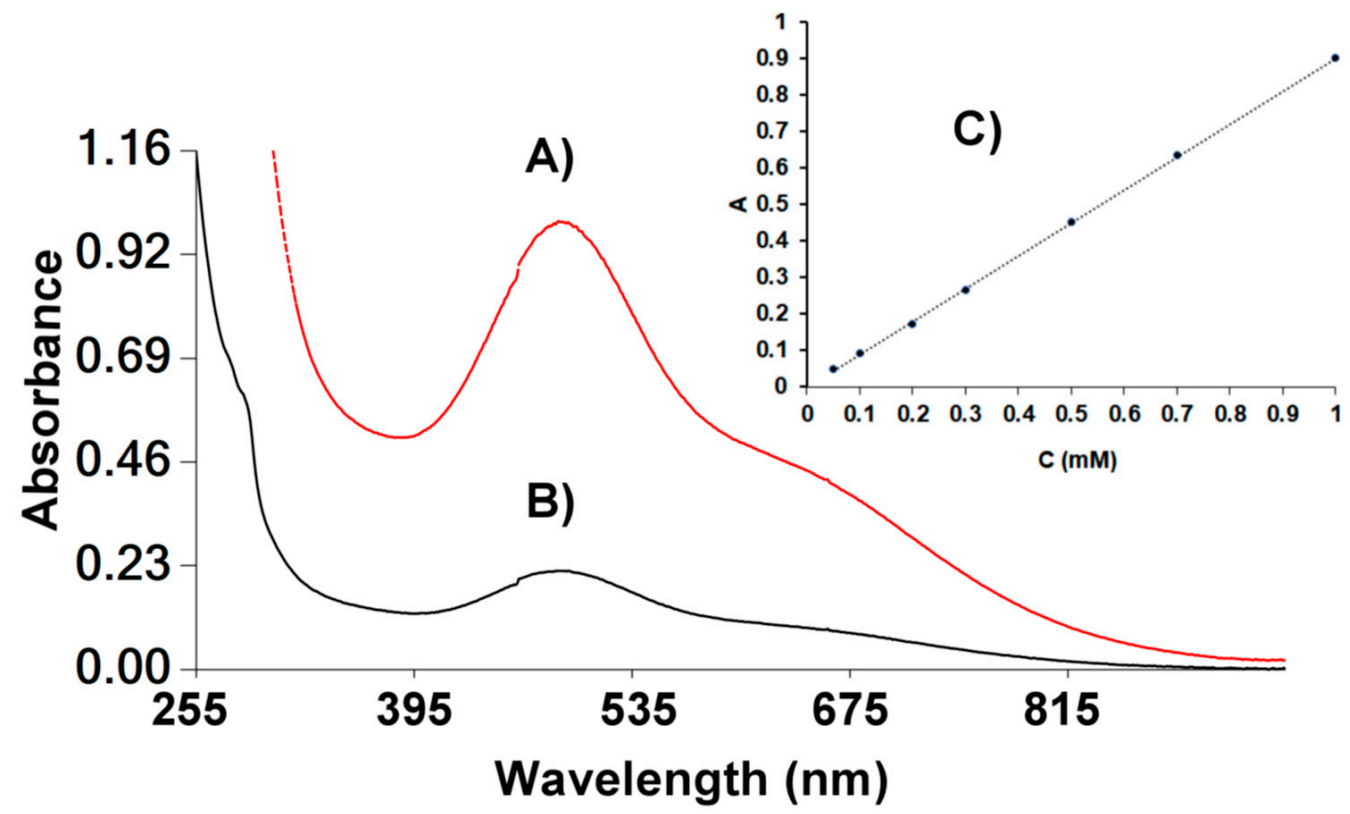

Figure 9. UV-vis spectra of DMSO- $d_{6}: \mathrm{D}_{2} \mathrm{O}(1: 9)$ solutions of $\mathbf{1}$ (A) $0.500 \mathrm{mM}$ and (B) $0.100 \mathrm{mM}$, (C) graph of the absorption at $490 \mathrm{~nm}$ vs. concentration.

\subsection{Reactivity with DPPH•}

The radical scavenging activity (RSC) values of the organic compounds and the complexes towards scavenging the DPPH${ }^{\bullet}$ radical are shown in Table 1. $\alpha$-tocTHMA and $\delta$-tocTHMA exhibit very low antioxidant activity, much lower than free $\alpha$-tocopherol. The 
reason for this low activity is the replacement of the labile phenoxy proton of $\alpha$-tocopherol with an inert ether bond of $\alpha$-tocTHMA and $\delta$-tocTHMA. Large number of vanadium complexes exhibit radical scavenging activity [50]. However, complexes 1-4 either did not show any or very little decrease of the peak intensity at $520 \mathrm{~nm}$, resulting in the conclusion that they do not have any antioxidant activity.

Table 1. Rate constants $\left(k_{2}\right)$ for the RSC of the compounds under study.

\begin{tabular}{|c|c|}
\hline Compounds & $\begin{array}{c}k_{2}\left(\mathrm{M}^{-1} \mathrm{~s}^{-1}\right) \\
\text { Toluene }\end{array}$ \\
\hline$\alpha$-tocТМНА & $7.0 \pm 0.16$ \\
\hline 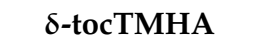 & $12.5 \pm 0.08$ \\
\hline $1 \mathrm{~m}$ & $-0.88 \pm 0.02$ \\
\hline $2 m$ & $-0.88 \pm 0.02$ \\
\hline 3 & $5.0 \pm 0.09$ \\
\hline 4 & $-0.75 \pm 0.02$ \\
\hline$\left[\mathrm{V}^{\mathrm{IV}} \mathrm{O}(\mathrm{acac})_{2}\right]$ & $6.8 \pm 0.3$ \\
\hline$\alpha$-tocopherol [33] & $560 \pm 80$ \\
\hline
\end{tabular}

\subsection{Oxidative Inducing Effect of Vanadium Compounds by EPR Spectroscopy}

The ability of the new vanadium compounds to produce radicals was examined by monitoring the generation of $\alpha$-tocopheryl radicals in olive oil by cw X-band EPR using 2D intensity vs. time experiments (Figure 10). The ability of complexes $\mathbf{1}$ and $\mathbf{2}$ were compared with that of the $\left[\mathrm{V}^{\mathrm{V}} \mathrm{O}(\mathrm{C} 18 \mathrm{DEA})\right]$ used in a previous study $[36,37]$. [ $\left.\mathrm{V}^{\mathrm{V}} \mathrm{O}(\mathrm{C} 18 \mathrm{DEA})\right]$ has been studied for its activity towards the production of radicals in olive oil, therefore, it is used in this work as a reference. Based on previous studies, it has been reported that $\mathrm{V}^{\mathrm{V}}$ and/or $\mathrm{V}^{\mathrm{IV}}$ coordinated catalytic sites are able to activate phenolics in the lipophilic matrix of oil mediated by dioxygen activation; in this oxidative environment free radicals are trapped by $\alpha$-tocopherol to give $\alpha$-tocopheryl radical. The generation of $\alpha$-tocopheryl radicals is monitored by X-band cw-EPR vs. time. The graph of the signal intensity vs. time is a very useful quantification tool to determine the ability of the complexes to initiate radicals. Experiments were run for two different quantities of each radical initiator for the study, $(0.490 \mu$ mole or $0.720 \mu$ mole $)$. The intensity of the EPR peaks, at the same time period after addition of the radical initiator in olive oil is higher for $\left[\mathrm{V}^{\mathrm{V}} \mathrm{O}(\mathrm{C} 18 \mathrm{DEA})\right]$ than $\mathbf{1}$, meaning that $\left[\mathrm{V}^{\mathrm{V}} \mathrm{O}(\mathrm{C} 18 \mathrm{DEA})\right]$ produces more $\alpha$-tocopheryl radicals than 1 . The intensity of the EPR signal is lower at higher concentrations of the radical initiator due to the faster oxidation of the polar antioxidants that regenerate $\alpha$-tocopherol in olive oil; the mechanism has been previously investigated [37]. Apparently, [ $\left.\mathrm{V}^{\mathrm{V}} \mathrm{O}(\mathrm{C} 18 \mathrm{DEA})\right]$, and consequently $\left[\mathrm{V}^{\mathrm{V}} \mathrm{O}(\beta\right.$-tocDEA $\left.)\right]$ which is stronger initiator than $\left[\mathrm{V}^{\mathrm{V}} \mathrm{O}(\mathrm{C} 18 \mathrm{DEA})\right][36]$, are by far much more potent radical initiators than $\mathbf{1}$.

$\left[\mathrm{V}^{\mathrm{V}} \mathrm{O}(\mathrm{C} 18 \mathrm{DEA})\right]$ and $\left[\mathrm{V}^{\mathrm{V}} \mathrm{O}(\beta\right.$-toc $\left.) \mathrm{DEA}\right]$ vanadium complexes have been reported to have high cytotoxicity [36]. If the cytotoxicity of the complexes is related to their oxidative power measured by EPR, then 1 is expected to be less cytotoxic than $\left[\mathrm{V}^{\mathrm{V}} \mathrm{O}(\mathrm{C} 18 \mathrm{DEA})\right]$ or $\left[\mathrm{V}^{\mathrm{V}} \mathrm{O}(\beta\right.$-toc $\left.) \mathrm{DEA}\right]$.

\subsection{Cytotoxic Activity}

None of the complexes exerted cytotoxic activity against the three cell lines, a fact that differentiated them significantly from the ligands. As seen in Figure 11, exposure of Cal33 cells for $24 \mathrm{~h}$ to increasing concentrations of the ligands and the complexes had no severe effect on the ability of the cells to proliferate (Figure 11A,C). Prolongation of the incubation time revealed that complexes 1 and 4 exerted a no-dose-dependent cytotoxicity across the different doses ( 1 to $100 \mu \mathrm{M}$ ) leading to a $40 \%$ reduction of cell population. On the contrary, the cytotoxic activity of the ligands $\mathrm{H}_{2} \alpha$-tocTHMA and $\mathrm{H}_{2} \delta$-tocTHMA as well as the complexes 2 and 3 was depicted mainly at doses higher than $25 \mu \mathrm{M}$. Order of 
cytotoxic activity $(100 \mu \mathrm{M})$ was found as following: $\mathrm{H}_{2} \delta$-tocTHMA $<\mathrm{H}_{2} \alpha$-tocTHMA $<4<$ $\mathbf{1}<3<2(24 \mathrm{~h}), \mathrm{H}_{2} \delta$-tocTHMA $=\mathrm{H}_{2} \alpha$-tocTHMA $<\mathbf{2}<\mathbf{3}<\mathbf{1}<4$ (48 h).

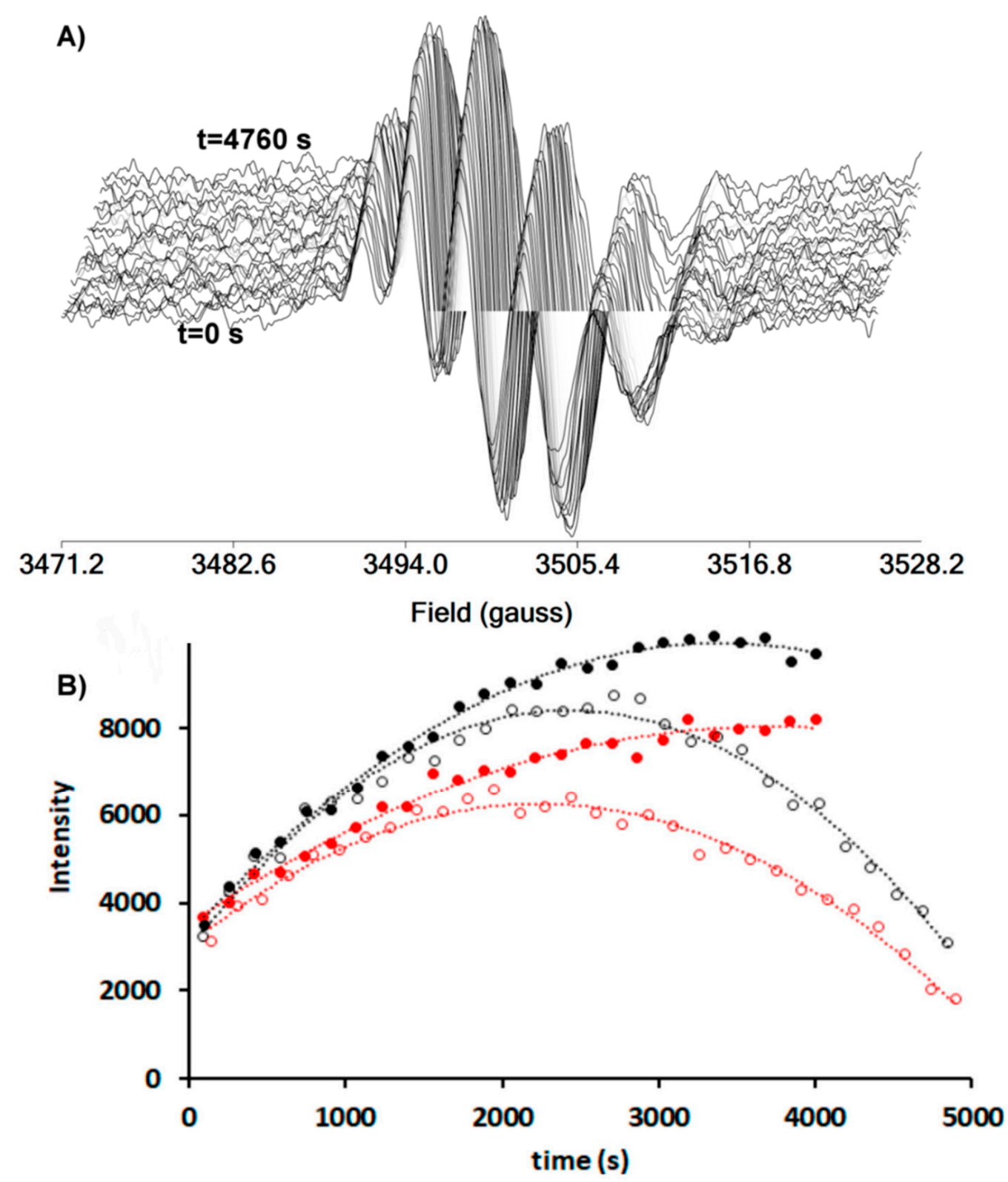

Figure 10. (A) X-band EPR spectra of virgin olive oil ( $0.500 \mathrm{~g})$ vs. time after addition of $\mathbf{1}(0.720 \mu$ mole $)$ at RT. The period between two continues spectra is $150 \mathrm{~s}$. The total number of spectra is 30 . (B) Intensity of the $\alpha$-tocopheryl radical signal in X-band EPR spectra vs. time after the addition of the radical initiator in extra virgin olive oil $(0.500 \mathrm{~g}), \mathrm{t}=0 \mathrm{~s}$. Complex 1 (red colour), [VO(C18DEA)] (black colour). Different concentrations of radical initiator with respect to each $\mathrm{V}^{\mathrm{V}}$ catalytic site per molecule: filled circles $(0.490 \mu$ mole $)$, open circles $(0.720 \mu$ mole $)$. The fitting curves have been generated from quadratic equations. 

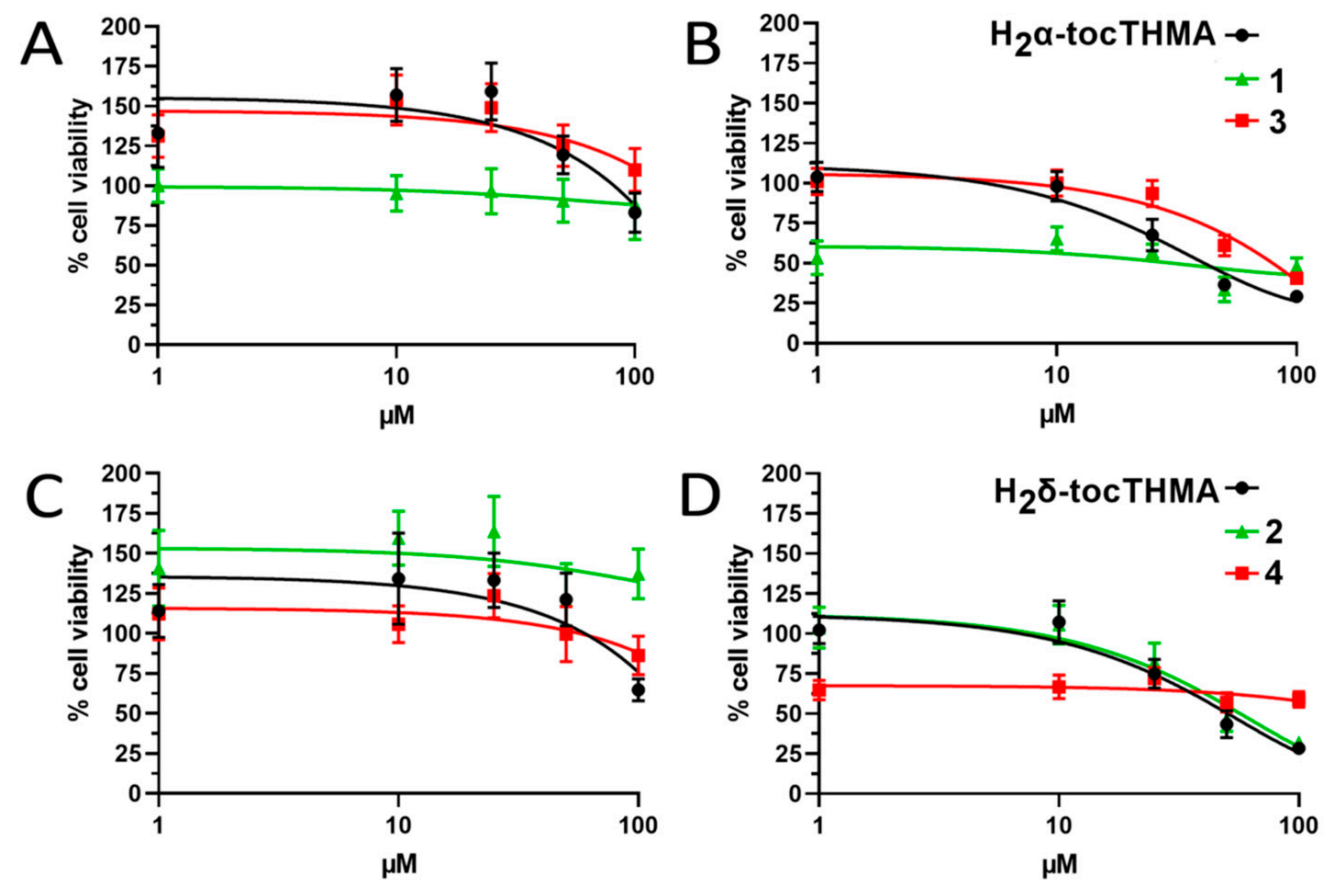

Figure 11. Cytotoxicity of $\mathrm{H}_{2} \alpha$-tocTHMA $(\mathbf{A}, \mathbf{B})$ and $\mathrm{H}_{2} \delta$-tocTHMA (C,D) complexes against Cal 33 cells after exposure for $24(\mathbf{A}, \mathbf{C})$ and $48 \mathrm{~h}(\mathbf{B}, \mathbf{D})$, respectively.

A similar cytotoxic profile was also seen against Hela cells (Figure 12). Twenty-four hours of exposure to the ligands and the complexes exerted a mild effect on cell viability even at the highest dose. At $48 \mathrm{~h}$ a slightly greater reduction in cell viability was recorded for both ligands and the complexes. Order of cytotoxic activity $(100 \mu \mathrm{M}): \mathrm{H}_{2} \alpha$-tocTHMA $<$ $\mathbf{3}<\mathbf{2}<\mathrm{H}_{2} \delta$-tocTHMA $<\mathbf{1}<\mathbf{4}(24 \mathrm{~h}), \mathrm{H}_{2} \alpha$-tocTHMA $<\mathbf{1}<\mathbf{3}=\mathrm{H}_{2} \delta$-tocTHMA $<\mathbf{2}<\mathbf{4}(48 \mathrm{~h})$.
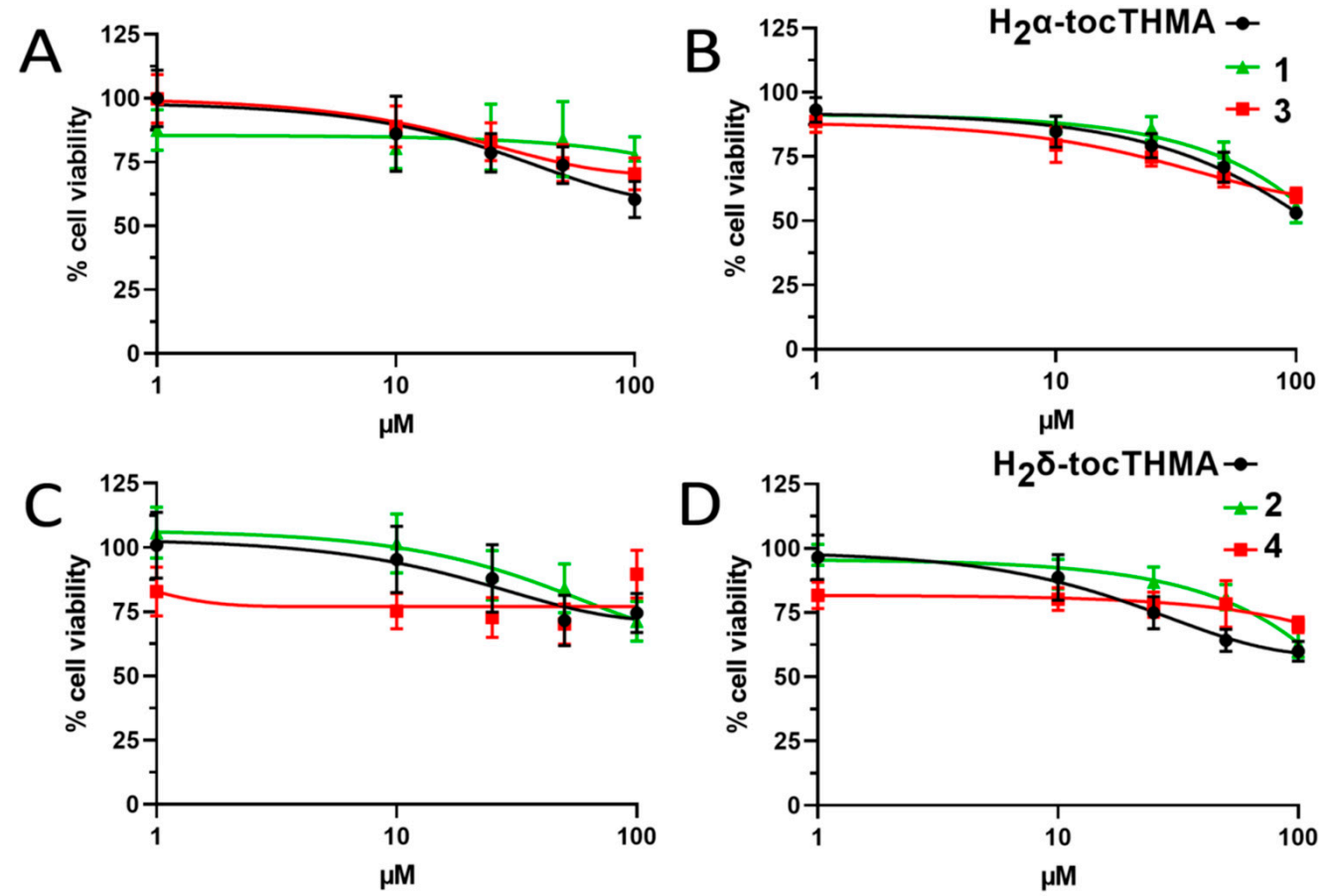

Figure 12. Cytotoxicity of $\mathrm{H}_{2} \alpha$-tocTHMA $(\mathbf{A}, \mathbf{B})$ and $\mathrm{H}_{2} \delta$-tocTHMA $(\mathbf{C}, \mathbf{D})$ complexes against HeLa cells after exposure for $24(\mathbf{A}, \mathbf{C})$ and $48 \mathrm{~h}(\mathbf{B}, \mathbf{D})$, respectively. 
Against embryonic mouse fibroblasts $(\mathrm{NIH} / 3 \mathrm{~T} 3)$, the complexes exerted minimal toxicity after $24 \mathrm{~h}$ of incubation (Figure $13 \mathrm{~A}, \mathrm{C}$ ). $\mathrm{H}_{2} \alpha$-tocTHMA presented a strong cytotoxic effect after $48 \mathrm{~h}$, a pattern similar to that seen against Cal 33 cells. On the contrary, complexes $\mathbf{1}$ and $\mathbf{3}$ had no effect on cell viability and remained relatively non-toxic (Figure 13B). Complex 4 maintains the same cytotoxic profile, as seen in HeLa and Cal33 cells, exerting a mild reduction in cell viability across the range of doses $(1-100 \mu \mathrm{M})$ whereas $\mathrm{H}_{2} \delta$-tocTHMA and 2 were cytotoxic at concentrations higher than $25 \mu \mathrm{M}$ (Figure 13D). Order of cytotoxic activity $(100 \mu \mathrm{M})$ was found as follows: $2>\mathrm{H}_{2} \delta$-tocTHMA $>\mathbf{1}=\mathrm{H}_{2} \alpha$-tocTHMA $>3>4$ (24 h), $\mathrm{H}_{2} \delta$-tocTHMA $=2>\mathrm{H}_{2} \alpha$-tocTHMA $>1>4>3(48 \mathrm{~h})$.
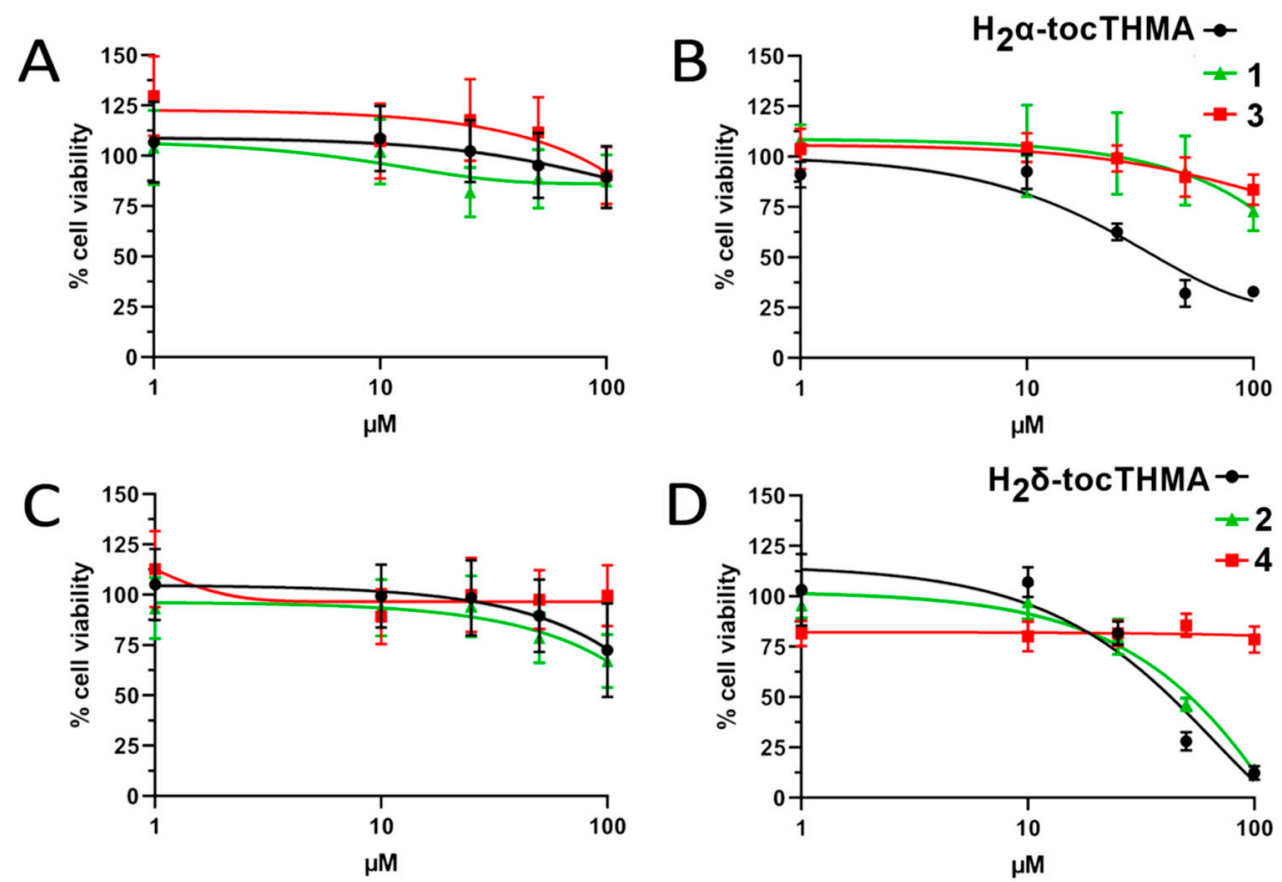

Figure 13. Cytotoxicity of $\mathrm{H}_{2} \alpha$-tocTHMA $(\mathbf{A}, \mathbf{B})$ and $\mathrm{H}_{2} \delta$-tocTHMA (C,D) complexes against $\mathrm{NIH} / 3 \mathrm{~T} 3$ cells after exposure for $24(\mathbf{A}, \mathbf{C})$ and $48 \mathrm{~h}(\mathbf{B}, \mathbf{D})$, respectively.

\section{Conclusions}

Stepwise substitution reactions of cyanuric chloride with $\alpha$ - or $\delta$-tocopherol and then with $\mathrm{N}$-methylhydroxylamine resulted in the synthesis of the amphiphilic $\mathrm{H}_{2} \alpha$-tocTHMA and $\mathrm{H}_{2} \delta$-tocTHMA ligands. Reaction of the ligands with either the $\mathrm{V}^{\mathrm{IV}}$ starting materials $\left[\mathrm{V}^{\mathrm{IV}} \mathrm{O}(\mathrm{acac})_{2}\right]$ or $\mathrm{V}^{\mathrm{IV}} \mathrm{OSO}_{4}$ afforded the complexes 1 and 2. Reaction of $\mathrm{Fe}^{\mathrm{III}} \mathrm{Cl}_{3}$ with $\mathrm{H}_{2} \alpha$ tocTHMA or $\mathrm{H}_{2} \delta$-tocTHMA resulted in the formation of complexes 3 and 4 respectively. The new compounds have been characterised by NMR, UV/Vis and infrared spectroscopies. The RSC activities for all compounds have been determined by the $\mathrm{DPPH}^{\bullet}$ assay and the results showed than none of the molecules, ligands or complexes, exhibits antioxidant activity. On the contrary, EPR spectroscopy showed that $\mathbf{1}$ and $\mathbf{2}$ are radical initiators. All complexes exhibit high hydrolytic stability even at low concentrations similar to those used in cell viability studies. All complexes, 1-4, do not exerted significant cytotoxic activity against NIH/3T3, Cal33 and HeLa cell lines. The low cytotoxic activity is attributed to the low antioxidant-prooxidant activity of the tocopherol-triazine conjugate molecules. This is in line with the fact that $\mathbf{1}$ and $\mathbf{2}$ are moderate radical initiators. Previous studies support that the tocopherol-metal complexes with the hydroxy group of chromanol accessible to metal ion coordination, are stronger radical initiators than $\mathbf{1}$ and $\mathbf{2}$, and they exert high cytotoxic activity. However, we cannot exclude the structural differences of the chelate moieties that might induce various biological responses. Currently, the vitamin E metal complexes are rare, and more work is required, including synthesis of new compounds with specific structural features, in order to understand the mechanism of their reactivity. 
Author Contributions: Conceptualization, A.D.K. and C.D.; data curation, M.L., I.H. and Y.V.S.; methodology, A.D.K., C.D., Y.V.S. and D.P.; writing—original draft, A.D.K., C.D. and Y.V.S.; writingreview and editing, A.D.K. and C.D. All authors have read and agreed to the published version of the manuscript.

Funding: This research received no external funding.

Institutional Review Board Statement: Not applicable.

Informed Consent Statement: Not applicable.

Data Availability Statement: Data is contained within the article.

Conflicts of Interest: The authors declare no conflict of interest.

\section{References}

1. Michibata,H.; Sakurai, H. Vanadium in Biological Systems; Chasteen, N.D., Ed.; Kluer Academic Publishers: Dordrecht, The Netherlands, 1990; pp. 153-171.

2. $\quad$ Crans, D.C.; Keramidas, A.D.; Hoover-Litty, H.; Anderson, O.P.; Miller, M.M.; Lemoine, L.M.; Pleasic-Williams, S.; Vandenberg, M.; Rossomando, A.J.; Sweet, L.J. Synthesis, structure, and biological activity of a new insulinomimetic peroxovanadium compound: Bisperoxovanadium imidazole monoanion. J. Am. Chem. Soc. 1997, 119, 5447-5448. [CrossRef]

3. Rehder, D. The coordination chemistry of vanadium as related to its biological functions. Coord. Chem. Rev. 1999, 182, 297-322. [CrossRef]

4. Kioseoglou, E.; Petanidis, S.; Gabriel, C.; Salifoglou, A. The chemistry and biology of vanadium compounds in cancer therapeutics. Coord. Chem. Rev. 2015, 301-302, 87-105. [CrossRef]

5. Levina, A.; Lay, P.A. Stabilities and Biological Activities of Vanadium Drugs: What is the Nature of the Active Species? Chem. Asian J. 2017, 12, 1692-1699. [CrossRef] [PubMed]

6. Harwood, C.S. Iron-Only and Vanadium Nitrogenases: Fail-Safe Enzymes or Something More? Annu. Rev. Microbiol. 2020, 74, 247-266. [CrossRef] [PubMed]

7. Amante, C.; De Sousa-Coelho, A.L.; Aureliano, M. Vanadium and melanoma: A systematic review. Metals 2021, 11, 828. [CrossRef]

8. Sciortino, G.; Maréchal, J.D.; Garribba, E. Integrated experimental/computational approaches to characterize the systems formed by vanadium with proteins and enzymes. Inorg. Chem. Front. 2021, 8, 1951-1974. [CrossRef]

9. Costa Pessoa, J.; Garribba, E.; Santos, M.F.A.; Santos, S. Vanadium and proteins: Uptake, transport, structure, activity and function. Coord. Chem. Rev. 2015, 301-302, 49-86. [CrossRef]

10. Pessoa, J.C.; Etcheverry, S.; Gambino, D. Vanadium compounds in medicine. Coord. Chem. Rev. 2015, 301-302, 24-48. [CrossRef]

11. Rehder, D. The future of/for vanadium. Dalton Trans. 2013, 42, 11749-11761. [CrossRef]

12. Crans, D.C.; Trujillo, A.M.; Pharazyn, P.S.; Cohen, M.D. How environment affects drug activity: Localization, compartmentalization and reactions of a vanadium insulin-enhancing compound, dipicolinatooxovanadium(V). Coord. Chem. Rev. 2011, 255, 2178-2192. [CrossRef]

13. McLauchlan, C.C.; Peters, B.J.; Willsky, G.R.; Crans, D.C. Vanadium-phosphatase complexes: Phosphatase inhibitors favor the trigonal bipyramidal transition state geometries. Coord. Chem. Rev. 2015, 301-302, 163-199. [CrossRef]

14. Willsky, G.R.; Chi, L.H.; Godzala, M.; Kostyniak, P.J.; Smee, J.J.; Trujillo, A.M.; Alfano, J.A.; Ding, W.; Hu, Z.; Crans, D.C. Antidiabetic effects of a series of vanadium dipicolinate complexes in rats with streptozotocin-induced diabetes. Coord. Chem. Rev. 2011, 255, 2258-2269. [CrossRef]

15. Crans, D.C.; Tarlton, M.L.; McLauchlan, C.C. Trigonal bipyramidal or square pyramidal coordination geometry? Investigating the most potent geometry for vanadium phosphatase inhibitors. Eur. J. Inorg. Chem. 2014, 2014, 4450-4468. [CrossRef]

16. Crans, D.C.; Schoeberl, S.; Gaidamauskas, E.; Baruah, B.; Roess, D.A. Antidiabetic vanadium compound and membrane interfaces: Interface-facilitated metal complex hydrolysis. J. Biol. Inorg. Chem. 2011, 16, 961-972. [CrossRef]

17. Sánchez-Lombardo, I.; Alvarez, S.; McLauchlan, C.C.; Crans, D.C. Evaluating transition state structures of vanadium-phosphatase protein complexes using shape analysis. J. Inorg. Biochem. 2015, 147, 153-164. [CrossRef]

18. Crans, D.C. Antidiabetic, Chemical, and Physical Properties of Organic Vanadates as Presumed Transition-State Inhibitors for Phosphatases. J. Org. Chem. 2015, 80, 11899-11915. [CrossRef]

19. Crans, D.C.; Henry, L.; Cardiff, G.; Posner, B.I. Developing Vanadium as an Antidiabetic or Anticancer Drug: A Clinical and Historical Perspective. Met. Ions Life Sci. 2019, 19, 203-230. [CrossRef]

20. Kostova, I. Titanium and vanadium complexes as anticancer agents. Anti-Cancer Agents Med. Chem. 2009, 9, 827-842. [CrossRef] [PubMed]

21. Bishayee, A.; Waghray, A.; Patel, M.A.; Chatterjee, M. Vanadium in the detection, prevention and treatment of cancer: The in vivo evidence. Cancer Lett. 2010, 294, 1-12. [CrossRef]

22. Evangelou, A.M. Vanadium in cancer treatment. Crit. Rev. Oncol. Hematol. 2002, 42, 249-265. [CrossRef]

23. León, I.E.; Cadavid-Vargas, J.F.; Di Virgilio, A.L.; Etcheverry, S. Vanadium, ruthenium and copper compounds: A new class of non-platinum Metallodrugs with anticancer activity. Curr. Med. Chem. 2016, 24, 112-148. [CrossRef] 
24. Crans, D.C.; Yang, L.; Haase, A.; Yang, X. Health Benefits of Vanadium and Its Potential as an Anticancer Agent. Met. Ions Life Sci. 2018, 18, 251-259. [CrossRef]

25. Doucette, K.A.; Hassell, K.N.; Crans, D.C. Selective speciation improves efficacy and lowers toxicity of platinum anticancer and vanadium antidiabetic drugs. J. Inorg. Biochem. 2016, 165, 56-70. [CrossRef] [PubMed]

26. Yan, B.; Stantic, M.; Zobalova, R.; Bezawork-Geleta, A.; Stapelberg, M.; Stursa, J.; Prokopova, K.; Dong, L.; Neuzil, J. Mitochondrially targeted vitamin E succinate efficiently kills breast tumour-initiating cells in a complex II-dependent manner. BMC Cancer 2015, 15, 401. [CrossRef] [PubMed]

27. Dong, L.F.; Grant, G.; Massa, H.; Zobalova, R.; Akporiaye, E.; Neuzil, J. $\alpha$-Tocopheryloxyacetic acid is superior to $\alpha$-tocopheryl succinate in suppressing HER2-high breast carcinomas due to its higher stability. Int. J. Cancer 2012, 131, 1052-1058. [CrossRef] [PubMed]

28. Dong, L.-F.; Neuzil, J. Vitamin E Analogues as Prototypic Mitochondria-Targeting Anti-cancer Agents. In Mitochondria: The Anti-Cancer Target for the Third Millennium; Neuzil, J., Pervaiz, S., Fulda, S., Eds.; Springer: Dordrecht, The Netherlands, 2014; pp. 151-181.

29. Kovarova, J.; Bajzikova, M.; Vondrusova, M.; Stursa, J.; Goodwin, J.; Nguyen, M.; Zobalova, R.; Pesdar, E.A.; Truksa, J.; Tomasetti, M.; et al. Mitochondrial targeting of $\alpha$-tocopheryl succinate enhances its anti-mesothelioma efficacy. Redox Rep. 2014, 19, 16-25. [CrossRef]

30. Yap, W.N.; Chang, P.N.; Han, H.Y.; Lee, D.T.W.; Ling, M.T.; Wong, Y.C.; Yap, Y.L. $\gamma$-Tocotrienol suppresses prostate cancer cell proliferation and invasion through multiple-signalling pathways. Br. J. Cancer 2008, 99, 1832-1841. [CrossRef]

31. Zingg, J.M. Molecular and cellular activities of vitamin E analogues. Mini-Rev. Med. Chem. 2007, 7, 545-560. [CrossRef]

32. Dunn, B.K.; Richmond, E.S.; Minasian, L.M.; Ryan, A.M.; Ford, L.G. A nutrient approach to prostate cancer prevention: The selenium and vitamin e cancer prevention trial (SELECT). Nutr. Cancer 2010, 62, 896-918. [CrossRef]

33. Vraka, P.S.; Drouza, C.; Rikkou, M.P.; Odysseos, A.D.; Keramidas, A.D. Synthesis and study of the cancer cell growth inhibitory properties of $\alpha-, \gamma$-tocopheryl and $\gamma$-tocotrienyl 2-phenylselenyl succinates. Bioorg. Med. Chem. 2006, 14, 2684-2696. [CrossRef]

34. Vraka, P.S.; Rikkou, M.N.; Drouza, C.; Keramidas, A.D.; Odysseos, A.D. Modulation of apoptotic signals with esterification of selenium and vitamin $\mathrm{E}$ in binary compounds. FEBS J. 2006, 273, 115.

35. Pussinen, P.J.; Karten, B.; Wintersperger, A.; Reicher, H.; McLean, M.; Malle, E.; Sattler, W. The human breast carcinoma cell line HBL-100 acquires exogenous cholesterol from high-density lipoprotein via CLA-1 (CD-36 and LIMPII analogous 1)-mediated selective cholesteryl ester uptake. Biochem. J. 2000, 349, 559-566. [CrossRef]

36. Hadjiadamou, I.; Vlasiou, M.; Spanou, S.; Simos, Y.; Papanastasiou, G.; Kontargiris, E.; Dhima, I.; Ragos, V.; Karkabounas, S.; Drouza, C.; et al. Synthesis of vitamin E and aliphatic lipid vanadium(IV) and (V) complexes, and their cytotoxic properties. J. Inorg. Biochem. 2020, 208, 111074. [CrossRef]

37. Drouza, C.; Dieronitou, A.; Hadjiadamou, I.; Stylianou, M. Investigation of Phenols Activity in Early Stage Oxidation of Edible Oils by Electron Paramagnetic Resonance and19F NMR Spectroscopies Using Novel Lipid Vanadium Complexes As Radical Initiators. J. Agric. Food. Chem. 2017, 65, 4942-4951. [CrossRef]

38. Crans, D.C.; Koehn, J.T.; Petry, S.M.; Glover, C.M.; Wijetunga, A.; Kaur, R.; Levina, A.; Lay, P.A. Hydrophobicity may enhance membrane affinity and anti-cancer effects of Schiff base vanadium(v) catecholate complexes. Dalton Trans. 2019, 48, 6383-6395. [CrossRef]

39. Lemons, B.G.; Richens, D.T.; Anderson, A.; Sedgwick, M.; Crans, D.C.; Johnson, M.D. Stabilization of a vanadium(v)-catechol complex by compartmentalization and reduced solvation inside reverse micelles. New J. Chem. 2013, 37, 75-81. [CrossRef]

40. Crans, D.C.; Keramidas, A.D.; Mahroof-Tahir, M.; Anderson, O.P.; Miller, M.M. Factors Affecting Solution Properties of Vana$\operatorname{dium}(V)$ Compounds: X-ray Structure of $\beta$-cis-NH4[VO2(EDDA)]. Inorg. Chem. 1996, 35, 3599-3606. [CrossRef]

41. Ekeltchik, I.; Gun, J.; Lev, O.; Shelkov, R.; Melman, A. Bis(hydroxyamino)triazines: Versatile and high-affinity tridentate hydroxylamine ligands for selective iron(III) chelation. Dalton Trans. 2006, 6, 1285-1293. [CrossRef] [PubMed]

42. Nikolakis, V.A.; Tsalavoutis, J.T.; Stylianou, M.; Evgeniou, E.; Jakusch, T.; Melman, A.; Sigalas, M.P.; Kiss, T.; Keramidas, A.D.; Kabanos, T.A. Vanadium(V) compounds with the bis-(hydroxylamino)-1,3,5-triazine ligand, H2bihyat: Synthetic, structural, and physical studies of [V 2 VO3(bihyat)2] and of the enhanced hydrolytic stability species cis-[VVO2(bihyat)]. Inorg. Chem. 2008, 47, 11698-11710. [CrossRef] [PubMed]

43. Stylianou, M.; Nikolakis, V.A.; Chilas, G.I.; Jakusch, T.; Vaimakis, T.; Kiss, T.; Sigalas, M.P.; Keramidas, A.D.; Kabanos, T.A. Molybdenum(VI) coordination chemistry of the N,N-disubstituted bis(hydroxylamido)-1,3,5-triazine ligand, H2bihyat. Waterassisted activation of the MoVI=O bond and reversible dimerization of cis-[MoVIO2(bihyat)] to [MoVI2O4(bihyat)2(H2O)2]. Inorg. Chem. 2012, 51, 13138-13147. [CrossRef]

44. Hadjithoma, S.; Papanikolaou, M.G.; Leontidis, E.; Kabanos, T.A.; Keramidas, A.D. Bis(hydroxylamino)triazines: High Selectivity and Hydrolytic Stability of Hydroxylamine-Based Ligands for Uranyl Compared to Vanadium(V) and Iron(III). Inorg. Chem. 2018, 57, 7631-7643. [CrossRef]

45. Chatterjee, P.B.; Abtab, S.M.T.; Bhattacharya, K.; Endo, A.; Shotton, E.J.; Teat, S.J.; Chaudhury, M. Hetero-bimetallic complexes involving vanadium(V) and rhenium(VII) centers, connected by unsupported $\mu$-oxido bridge: Synthesis, characterization, and redox study. Inorg. Chem. 2008, 47, 8830-8838. [CrossRef]

46. Espín, J.C.; Soler-Rivas, C.; Wichers, H.J.; García-Viguera, C. Anthocyanin-based natural colorants: A new source of antiradical activity for foodstuff. J. Agric. Food. Chem. 2000, 48, 1588-1592. [CrossRef] 
47. Avdikos, A.; Karkabounas, S.; Metsios, A.; Kostoula, O.; Havelas, K.; Binolis, J.; Verginadis, I.; Hatziaivazis, G.; Simos, I.; Evangelou, A. Anticancer effects on leiomyosarcoma-bearing Wistar rats after electromagnetic radiation of resonant radiofrequencies. Hell. J. Nucl. Med. 2007, 10, 95-101.

48. Drouza, C.; Keramidas, A.D. Solid state and aqueous solution characterization of rectangular tetranuclear V(IV/V)-psemiquinonate/hydroquinonate complexes exhibiting a proton induced electron transfer. Inorg. Chem. 2008, 47, 7211-7224. [CrossRef]

49. Drouza, C.; Stylianou, M.; Papaphilippou, P.; Keramidas, A.D. Structural and electron paramagnetic resonance (EPR) characterization of novel vanadium(V/IV) complexes with hydroquinonate-iminodiacetate ligands exhibiting "noninnocent"activity. Pure Appl. Chem. 2013, 85, 329-342. [CrossRef]

50. Etcheverry, S.B.; Williams, P.A.M. Medicinal chemistry of copper and vanadium bioactive compounds. In New Developments in Medicinal Chemistry; Nova Science Publishers, Inc.: Hauppauge, NY, USA, 2009; pp. 105-129. 